\title{
Evolution of the complex refractive index in the UV spectral region in ageing secondary organic aerosol
}

\author{
J. M. Flores ${ }^{1}$, D. F. Zhao ${ }^{2}$, L. Segev ${ }^{1}$, P. Schlag ${ }^{2}$, A. Kiendler-Scharr ${ }^{2}$, H. Fuchs ${ }^{2}$, Å. K. Watne ${ }^{3}$, N. Bluvshtein ${ }^{1}$, \\ Th. F. Mentel ${ }^{2}$, M. Hallquist ${ }^{3}$, and Y. Rudich ${ }^{1}$ \\ ${ }^{1}$ Weizmann Institute of Science, Department of Earth and Planetary Sciences, Rehovot 76100, Israel \\ ${ }^{2}$ Institut für Energie und Klimaforschung: Troposphäre (IEK-8), Forschungszentrum Jülich, 52425 Jülich, Germany \\ ${ }^{3}$ Department of Chemistry and Molecular Biology, Atmospheric Science, University of Gothenburg, 41296 Gothenburg, \\ Sweden
}

Correspondence to: Y. Rudich (yinon.rudich@weizmann.ac.il)

Received: 14 January 2014 - Published in Atmos. Chem. Phys. Discuss.: 14 February 2014

Revised: 5 May 2014 - Accepted: 7 May 2014 - Published: 11 June 2014

\begin{abstract}
The chemical and physical properties of secondary organic aerosol (SOA) formed by the photochemical degradation of biogenic and anthropogenic volatile organic compounds (VOC) are as yet still poorly constrained. The evolution of the complex refractive index (RI) of SOA, formed from purely biogenic VOC and mixtures of biogenic and anthropogenic VOC, was studied over a diurnal cycle in the SAPHIR photochemical outdoor chamber in Jülich, Germany. The correlation of RI with SOA chemical and physical properties such as oxidation level and volatility was examined. The RI was retrieved by a newly developed broadband cavity-enhanced spectrometer for aerosol optical extinction measurements in the UV spectral region (360 to $420 \mathrm{~nm}$ ). Chemical composition and volatility of the particles were monitored by a high-resolution time-of-flight aerosol mass spectrometer, and a volatility tandem differential mobility analyzer. SOA was formed by ozonolysis of either (i) a mixture of biogenic VOC ( $\alpha$-pinene and limonene), (ii) biogenic VOC mixture with subsequent addition of an anthropogenic VOC ( $p$-xylene- $\mathrm{d}_{10}$ ), or (iii) a mixture of biogenic and anthropogenic VOC. The SOA aged by ozone/OH reactions up to $29.5 \mathrm{~h}$ was found to be non-absorbing in all cases. The SOA with $p$-xylene- $\mathrm{d}_{10}$ showed an increase of the scattering component of the RI correlated with an increase of the $\mathrm{O} / \mathrm{C}$ ratio and with an increase in the SOA density. There was a greater increase in the scattering component of the RI when the SOA was produced from the mixture of biogenic VOCs and anthropogenic VOC than from the sequential addition of the VOCs after approximately the same ageing time. The in-
\end{abstract}

crease of the scattering component was inversely correlated with the SOA volatility. Two RI retrievals determined for the pure biogenic SOA showed a constant RI for up to $5 \mathrm{~h}$ of ageing. Mass spectral characterization shows the three types of the SOA formed in this study have a significant amount of semivolatile components. The influence of anthropogenic VOCs on the oxygenated organic aerosol as well as the atmospheric implications are discussed.

\section{Introduction}

The interaction between aerosols and incoming solar radiation plays an important role in the radiative balance of Earth's atmosphere. Aerosols containing light-absorbing carbonaceous species are a major contributor to the direct and indirect effects on the climate system (Koren et al., 2008; Andreae and Ramanathan, 2013; Bond et al., 2013). Black carbon, which is the dominant absorber of solar radiation in the atmosphere, has fairly well defined optical properties with an estimate of the industrial-era mean direct radiative forcing of approximately $+1.1 \mathrm{~W} \mathrm{~m}^{-2}$ (Bond et al., 2013). However, the optical properties of light-absorbing organic particles, or "brown" carbon (Andreae and Gelencsér, 2006), which may account for $10-40 \%$ of the total light absorption in the atmosphere, and on snow and ice (Park et al., 2010; Bahadur et al., 2012; Cappa et al., 2012; Chung et al., 2012; Kirchstetter and Thatcher, 2012; Feng et al., 2013; Bond et al., 2013), are still poorly constrained. Recent studies have estimated 
the global radiative forcing of brown carbon to be 0.10 $0.25 \mathrm{~W} \mathrm{~m}^{-2}$, with higher values on regional scales (Bond et al., 2013; Feng et al., 2013). Brown carbon is mainly produced by combustion sources, especially biomass burning, but it has been hypothesized that it can also be produced by atmospheric chemical reactions; for example in the formation of secondary organic aerosols (SOA). SOA can account for $71 \%$ of the total organic aerosol (OA) sources, and up to $85 \%$ when ageing of primary to secondary OA is included (Spracklen et al., 2011). It is presumed that as SOA ages in the atmosphere, high-molecular-weight compounds can form, subsequently enhancing light absorption. For example, Lambe et al. (2013) showed that the mass absorption coefficient (MAC) at $\lambda=405 \mathrm{~nm}$ of SOA from biogenic and anthropogenic sources oxidized with $\mathrm{OH}$ increases with an increasing oxidation level, but has an overall negligible absorption at $\lambda=532 \mathrm{~nm}$.

It is important to understand the production of SOA from atmospheric oxidation of biogenic and anthropogenic volatile organic compounds (VOC). Estimations suggest that globally SOA is dominated by biogenic VOC precursors (BVOC), resulting in $90 \%$ biogenic SOA (BSOA) and $10 \%$ anthropogenic SOA (ASOA) (Hallquist et al., 2009). However, in many case studies, observations of SOA can only be explained assuming enhancement of SOA production by anthropogenic influences (Spracklen et al., 2011). Several studies have shown that the interaction between biogenic volatile organic compounds and anthropogenic VOCs (AVOCs) can significantly affect the properties of SOA (Kautzman et al., 2010; Glasius et al., 2011; Hoyle et al., 2011; Spracklen et al., 2011; Emanuelsson et al., 2013a). Two recent studies have shed some light on the chemical behavior of AVOCs and BVOCs. Hildebrandt et al. (2011) studied the mass yields of SOA formed from mixtures of biogenic and anthropogenic precursors and found that the yields can be parameterized by assuming a common organic phase for partitioning, and that the SOA derived from mixtures of AVOC and BVOC (ABSOA) can be treated as an ideal mixture. Similarly, Emanuelsson et al. (2013a) found that the SOA yields and oxidation levels can be described as linear combinations of the corresponding properties of the pure biogenic and anthropogenic systems.

The complex refractive index (RI; $m=n+i k$ ) is one of the intrinsic optical properties of aerosols. The real $(n)$ and imaginary $(k)$ parts express the extent of scattering and absorption of light by the aerosol, respectively. Several studies have retrieved SOA refractive indices in the laboratory (Schnaiter et al., 2003; Yu et al., 2008; Wex et al., 2009; Kim et al., 2010; Lang-Yona et al., 2010; Nakayama et al., 2010, 2012, 2013; Redmond and Thompson, 2011; Kim et al., 2012; Lambe et al., 2013; Kim and Paulson, 2013); however, recent studies exploring the evolution of the optical properties of SOA formed from mixtures of AVOCs and BVOCs are not available in the literature. Recently it has become possible to retrieve the RI of aerosols as a function of wavelength using broadband cavity-enhanced spectroscopy (Washenfelder et al., 2013; Wilson et al., 2013; Zhao et al., 2013). In this paper, by using the approach described in Washenfelder et al. (2013), we report the evolution of the complex refractive index in the UV spectral region of ABSOA formed from mixtures of biogenic (a mixture of $\alpha$-pinene and limonene) and anthropogenic $\left(p\right.$-xylene- $\left.\mathrm{d}_{10}\right)$ precursors at low $\mathrm{NO}_{\mathrm{x}}$ levels. Additionally, we explore the relationship between the SOA oxidation level, $\mathrm{H} / \mathrm{C}$ ratio, and volatility with the RI by following the SOA ageing process due to $\mathrm{OH}$ oxidation reactions in the outdoor atmospheric simulation chamber SAPHIR over a diurnal cycle.

\section{Experiments, instrumentation, and methods}

\subsection{Experiments}

The experiments took place in the outdoor atmospheric simulation chamber SAPHIR at the Forschungszentrum Jülich, in Jülich, Germany. The SAPHIR chamber has been previously described in detail (Bohn et al., 2005; Rohrer et al., 2005); only a short description is given here. SAPHIR is a double-walled Teflon chamber with a volume of $270 \mathrm{~m}^{3}$. It is operated with synthetic air (Linde Lipur, purity $99.9999 \%$ ) and kept at a slight overpressure of about $50 \mathrm{~Pa}$. To maintain the overpressure in the chamber and compensate for the sampling by the instruments, a continuous flow of $7-9 \mathrm{~m}^{3} \mathrm{~h}^{-1}$ of synthetic air is maintained throughout the experiments. A fan is used to ensure mixing of the injected trace gases, and the chamber is equipped with a Louvre system to either open and expose it to natural sunlight or close it to simulate nighttime processes.

To measure the evolution of the generated SOA, the experiments were performed as follows: after the chamber was flushed throughout the night, synthetic air with about $40 \mathrm{ppm}$ of $\mathrm{CO}_{2}$ was injected into the chamber and the relative humidity was increased to $\sim 75 \%$. Then the chosen VOCs were introduced and allowed to mix for approximately $2 \mathrm{~h}$, followed by injection of $200 \mathrm{ppb}$ of ozone and opening of the roof, which marks the beginning of the experiment. The SOA was allowed to age for at least $29 \mathrm{~h}$, and the roof was only closed at the end of the experiment. This allowed for simulation of a diurnal cycle through which the aerosols aged. Three experiments were performed in this study: (1) two biogenic VOCs, $48 \mathrm{ppb}$ of $\alpha$-pinene (SigmaAldrich, 80605-1ML, $\geq 98.5 \%$; St. Louis, MO, USA) and $48 \mathrm{ppb}$ of limonene (Sigma-Aldrich, 62118, $\geq 99 \%$ ), were mixed and added as precursors with an initial $\mathrm{OH}$ concentration of $7.4 \times 10^{6} \mathrm{~cm}^{-3}$, referred to as the BVOC experiment; (2) a sequential addition to the BVOC mixture of $39 \mathrm{ppb}$ of $\alpha$-pinene and $39 \mathrm{ppb}$ of limonene followed by $51 \mathrm{ppb}$ of $p$-xylene- $\mathrm{d}_{10}$ (Sigma-Aldrich, 175927-5G, 99 atom \% D) added $5 \mathrm{~h}$ after the BVOCs, with an initial $\mathrm{OH}$ concentration of $7.8 \times 10^{6} \mathrm{~cm}^{-3}$, referred to as the sequential experiment; 
and (3) $42 \mathrm{ppb}$ of $\alpha$-pinene, $42 \mathrm{ppb}$ of limonene, and $90 \mathrm{ppb}$ of $p$-xylene- $\mathrm{d}_{10}$ were mixed and added as precursors with an $\mathrm{OH}$ concentration of $8.0 \times 10^{6} \mathrm{~cm}^{-3}$, referred to as the mixture experiment. The three experiments performed are summarized in Table 1, and Fig. 1 shows a schematic of the experimental procedure.

\subsection{Analytical instrumentation}

The SAPHIR chamber was equipped with temperature, water content, $\mathrm{O}_{3}$, $\mathrm{NO}$, and $\mathrm{NO}_{2}$ monitors. $\mathrm{NO}$ and $\mathrm{NO}_{2}$ measurements were performed with a chemiluminescence analyzer (Eco Physics AG, TR480, Duerten, Switzerland) equipped with a photolytic converter (Eco Physics AG, PLC760). Ozone was measured by a UV absorption spectrometer (ANSYCO GmbH, model O341M, Karlsruhe, Germany). The detection limit and accuracy were $0.5 \mathrm{ppbv}$ and $5 \%$, respectively. Hydroxyl radical $(\mathrm{OH})$ concentrations were measured using laser-induced fluorescence (LIF). The uncertainty of the $\mathrm{OH}$ measurement, determined by the accuracy of the calibration of the LIF instrument, is $10 \%(1 \sigma)$. The LIF instrument is described in detail by Fuchs et al. (2012). The $\mathrm{OH}$ radicals in these experiments are predominantly formed from the ozonolysis of the VOCs, and to a minor extent by HONO and ozone photolysis (Rohrer et al., 2005). The absolute water content was measured with a cavity ring down Picarro analyzer (Picarro G2380, Santa Clara, CA, USA), and was used to calculate the relative humidity. A spectral radiometer (Bohn et al., 2005) was used to measure the actinic flux, the VOCs' concentrations were monitored by a proton transfer reaction mass spectrometer (PTR-MS) (Jordan et al., 2009), and the total particle concentration and number size distributions were measured by a condensation particle counter (UWCPC, model 3786, TSI Inc., Shoreview, MN, USA) and a scanning mobility particle sizer (SMPS, TSI 3081 and TSI 3786). Figure 2 shows the time series for the different chamber variables measured for each of the three experiments. The $\mathrm{NO}_{\mathrm{x}}$ data are not shown as it was within or below detection limit for all experiments.

\subsection{Measurement of SOA chemical composition}

The chemical composition of the SOA was measured with a high-resolution time-of-flight aerosol mass spectrometer (HR-ToF-AMS, Aerodyne Research Inc., Billerica, MA, USA) (DeCarlo et al., 2006) operated alternatingly between the MS and particle-time-of-flight mode. The MS mode (in which the ion signals are integrated over all particle sizes) was used to determine the SOA composition. The degree of oxidation of the SOA was characterized by deriving the $\mathrm{O} / \mathrm{C}$ and $\mathrm{H} / \mathrm{C}$ ratios (Aiken et al., 2007, 2008), and by determining the ratios $f_{44}$ and $f_{43}$ (defined as the fractions of the signal at $m / z=44$ and 43 of the total organics measured by the AMS) and applying them as suggested by Ng et al. (2010). The corrections for the errors due to gaseous components preceded the calculation of the $\mathrm{O} / \mathrm{C}$ ratio, $f_{44}$, and $f_{43}$ according to the generalized method by Allan et al. (2004).

The density $(\rho)$ of the particles, assuming that they are spherical, was calculated using Eq. (1) (DeCarlo et al., 2004):

$\rho=\frac{d_{\mathrm{va}}}{d_{\mathrm{m}}} \rho_{o}$,

where $d_{\mathrm{va}}$ is the vacuum aerodynamic diameter (obtained from the particle time-of-flight measurements from the ToFAMS), $d_{\mathrm{m}}$ is the mode mobility diameter from the SMPS size distributions, and $\rho_{o}$ is the standard density. Calculations of the density are only presented up to $15 \mathrm{~h}$ after the experiments began; after that time the vacuum aerodynamic diameter determination became less accurate, probably due to low particle concentrations, and consequently the $\rho$ values became unrealistically variable. However, we do not expect the density trends and values to change significantly after this point.

\subsection{Measurement of SOA volatility}

The volatility of the SOA was determined with a volatility tandem differential mobility analyzer (VTDMA); see Jonsson et al. (2007) and Salo et al. (2011) for details. The VTDMA consisted of a differential mobility analyzer (DMA, TSI 3081), eight temperature-controlled ovens, and an SMPS (TSI 3081, TSI 3022). First, a narrow particle size distribution was chosen with the first DMA, then the size-selected aerosol was directed through one of the eight temperaturecontrolled oven units under laminar flow conditions, and finally classified with the SMPS. To prevent recondensation of evaporated gases, activated charcoal diffusion scrubbers were used at the exit of the ovens. Each heated oven consists of a $50 \mathrm{~cm}$ diameter stainless steel tube mounted on an aluminum block with a heating element set independently to temperature values between 298 and $563 \mathrm{~K} \pm 0.1 \mathrm{~K}$. The sample flow of $0.3 \mathrm{Lpm}$ was switched between the ovens, yielding a residence time in the heated part of the oven of $2.8 \mathrm{~s}$. The aerosol volume fraction remaining (VFR) was calculated assuming spherical particles (Ofner et al., 2011) for the range of elevated temperatures. The VFR decreases with increasing temperature and the data were fitted to a sigmoidal function as has been described by Emanuelsson et al. (2013b). From the sigmoidal fits it is possible to obtain the temperature where $50 \%$ of the particle volume has evaporated, $T_{\text {VFR0.5 }} \cdot T_{\text {VRF0.5 }}$ was determined every $2 \mathrm{~h}$ for each experiment, for particles with $100 \mathrm{~nm}$ diameter for the first $6 \mathrm{~h}$, and $200 \mathrm{~nm}$ diameter for the remaining time.

\subsection{Measurement of SOA optical properties}

A dual-channel broadband cavity-enhanced spectrometer (BBCES) was used to measure the aerosol optical extinction and retrieve the complex refractive indices between 360 and $420 \mathrm{~nm}$ (at $0.5 \mathrm{~nm}$ resolution). This instrument follows the 


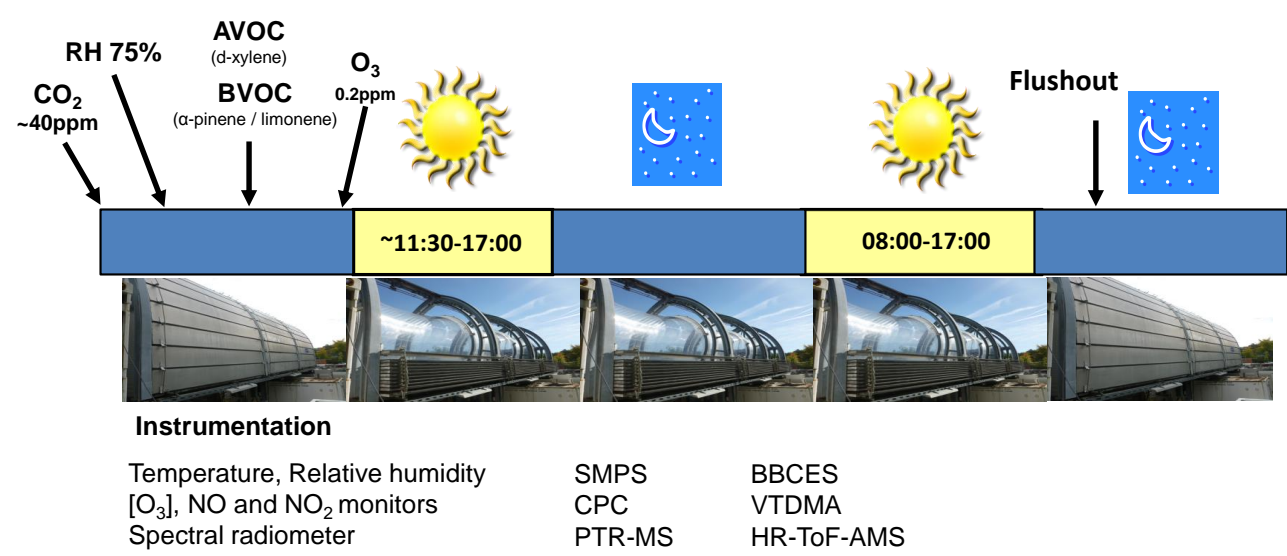

Figure 1. Schematic of the experimental procedure and instrumentation used for measuring the evolution of secondary organic aerosol over a diurnal cycle. All experiments began around 11:30 local time. Acronyms: SMPS - scanning mobility particle sizer; CPC - condensation particle counter; PTR-MS - proton transfer reaction mass spectrometer; BBCES - broadband cavity-enhanced spectrometer; VTDMA volatility tandem differential mobility analyzer; HR-ToF-AMS - high-resolution time-of-flight aerosol mass spectrometer.

Table 1. Description of the experiments performed in this study.

\begin{tabular}{|c|c|c|c|c|c|c|}
\hline Experiment & Description & $\begin{array}{l}\text { VOC } \\
(\mathrm{ppb})\end{array}$ & $\begin{array}{c}\text { Initial }[\mathrm{OH}] \\
\left(\times 10^{6} \mathrm{molec}^{-3}\right)\end{array}$ & $\begin{array}{l}{\left[\mathrm{NO}_{\mathrm{x}}\right]} \\
(\mathrm{ppbv})\end{array}$ & $\begin{array}{c}\text { Local time } \\
\text { experiments began }\end{array}$ & $\begin{array}{c}\text { Total } \\
\text { duration }\end{array}$ \\
\hline BVOCs & BVOCs mix only & $\begin{array}{l}\alpha \text {-pinene, limonene } \\
(48,48)\end{array}$ & 7.4 & $<0.25$ & $11: 30$ & $\sim 50 \mathrm{~h}$ \\
\hline Sequential & $\begin{array}{l}\text { BVOCs mix } \& p \text {-xylene- } \mathrm{d}_{10} \\
\left(p \text {-xylene- } \mathrm{d}_{10} \text { added } 5 \mathrm{~h} \text { after }\right. \\
\text { BVOCs mix })\end{array}$ & $\begin{array}{l}\alpha \text {-pinene, limonene } \\
(39,39) \\
p \text {-xylene-d } 10 \\
(51)\end{array}$ & 7.8 & $<0.30$ & $11: 37$ & $\sim 29 \mathrm{~h}$ \\
\hline Mixture & $\begin{array}{l}\text { BVOCs mix \& } p \text {-xylene- } \mathrm{d}_{10} \\
\text { (added together) }\end{array}$ & $\begin{array}{l}\alpha \text {-pinene, limonene } \\
(42,42) \\
p \text {-xylene-d } \mathrm{d}_{10} \\
(90)\end{array}$ & 8.0 & $<0.25$ & $11: 33$ & $\sim 29.5 \mathrm{~h}$ \\
\hline
\end{tabular}

design described in Washenfelder et al. (2013), and only a brief description and main differences are given here. The BBCES consist of two optical cavities and a CPC (TSI 3575) connected in series. One channel covers the $360-390 \mathrm{~nm}$ spectral range and the other covers that of $390-420 \mathrm{~nm}$. Incoherent light emitted from two LEDs with center wavelengths of 370.2 (M365L2, Thorlabs, Newton, NJ, USA) and $407.1 \mathrm{~nm}$ (M405L2, Thorlabs) is passively coupled into each optical cavity with two highly reflective plano-concave mirrors (Advanced Thin Films) situated opposite of each other. The light exiting the cavity is directed into an optical fiber and transmitted to a $164 \mathrm{~mm}$ focal length CzernyTurner spectrometer (Shamrock SR-163, Andor Technology, Belfast, UK) with a cooled charge-coupled device (CCD) array detector (DU920P-BU, Andor Technology). The spectrometer was calibrated by a reference $\mathrm{Hg}-\mathrm{Ar}$ lamp. The extinction coefficient $\left(\alpha_{\text {ext }}\right)$ of the aerosol is determined from the change in light intensity of the filled cavity relative to a particle-free cavity, taking into account the mirror reflectivity and the Rayleigh scattering of the carrier gas (Washenfelder et al., 2013).
It has been previously shown that the RI of the aerosol can be retrieved by measuring several particle diameters (assuming the composition of each selected diameter to be the same) and fitting a theoretical Mie curve to the measured extinction cross sections at a specific wavelength (Pettersson et al., 2004; Lack et al., 2006; Abo Riziq et al., 2007; LangYona et al., 2009; Miles et al., 2010; Bluvshtein et al., 2012; Flores et al., 2012; Washenfelder et al., 2013). The aerosol optical cross section, $\sigma_{\text {ext }}\left(\mathrm{cm}^{2}\right)$, is determined by Eq. (2):

$\sigma_{\text {ext }}\left(\lambda, D_{\mathrm{p}}, m\right)=\frac{\alpha_{\text {ext }}\left(\lambda, D_{\mathrm{p}}, m\right)}{N\left(D_{\mathrm{p}}\right)}$,

where $\lambda$ is the wavelength of the incidence light, $D_{\mathrm{p}}$ is the particle mode diameter, $m$ is the complex refractive index, and $N\left(D_{\mathrm{p}}\right)$ is the particle number concentration $\left(\mathrm{cm}^{-3}\right)$. Particles were size-selected between 175 and $300 \mathrm{~nm}$ in $25 \mathrm{~nm}$ steps (diameters larger than $250 \mathrm{~nm}$ could only be selected towards the end of the experiments). To measure the optical cross section of the size-selected SOA from the chamber, aerosol from the SAPHIR chamber was sampled at $1360 \mathrm{~cm}^{3} \mathrm{~min}^{-1}$, passed through a diffusion dryer 

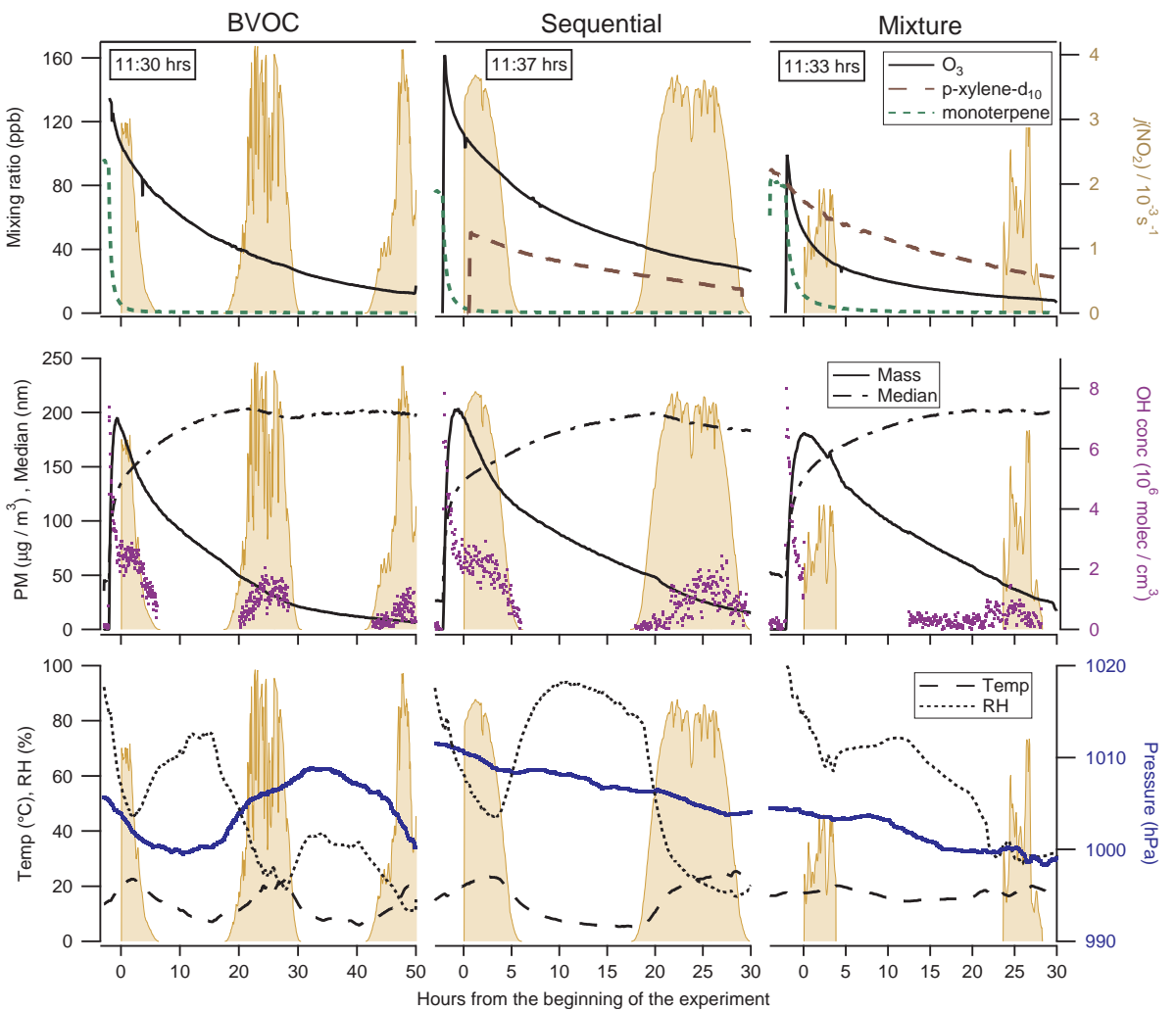

Figure 2. Time series of the three experiments performed. The BVOC, sequential, and mixture experiments are shown in the left, middle, and right column, respectively. The mixing ratio of ozone (black line), the mixture of $\alpha$-pinene and limonene (monoterpenes, dotted green line), and $p$-xylene- $\mathrm{d}_{10}$ (red dashed line) are shown in the top panels. The total mass (black line), median diameter (black dash-dot line), and $\mathrm{OH}$ concentration (purple dots) are shown in the middle panels. The temperature (black dash line), relative humidity (black dotted line), and pressure (blue dots) are shown in the lower panels. The photolysis rates of $\mathrm{NO}_{2}$ (orange area) are presented in all panels to indicate the diurnal cycles; the rate values are shown on the top-right axis. $\mathrm{NO}_{\mathrm{x}}$ levels were below $1 \mathrm{ppbv}$ and are not shown here. The local time at which each experiment began is shown in the top panels.

(RH $<30 \%$ ), size-selected with a DMA (TSI 3081) (with a sheath flow of $11.5 \mathrm{Lpm})$, passed through the BBCES, and counted by the CPC. Each size selection measurement is an average of 150 spectra integrated for $0.3 \mathrm{~s}$. The particle concentration was corrected for dilution by the BBCES mirror purge flows $\left(170 \mathrm{~cm}^{3} \mathrm{~min}^{-1}\right)$. The measured extinction cross sections were corrected for multiply charged particles using the closest measured size distributions from the SMPS connected directly to the SAPHIR chamber and the Wiedensohler charge distribution parameterization (Wiedensohler, 1988, with subsequent errata). Size selection measurements were done, if possible, approximately every $2 \mathrm{~h}$ and in parallel with the thermal characterization using the VTDMA. To retrieve the real and imaginary components of the RI, the retrieval algorithm was limited to searching for $n \geq 1$ and $k \geq 0$, their physical boundaries.

\section{Results}

\subsection{Refractive indices of SOA from pure BVOC and mixtures of BVOC and AVOC}

Oxidative ageing can cause changes in the RI of SOA (Liu and Daum, 2008; Cappa et al., 2011; Nakayama et al., 2012, 2013; Lambe et al., 2013), as the chemical speciation, mean molecular weight, density, and polarizability of the SOA change with ageing. For all retrievals in this study, the imaginary part reached zero $\left({ }_{-0.00}^{+0.03}\right)$ at all wavelengths; in other words, there was no detectable absorption under the conditions in this study. Consequently, only the retrieved real part of the RI as a function of wavelength between 360 and $420 \mathrm{~nm}$ for the three different experiments performed is shown in Fig. 3. For clarity, the shown retrieved real parts are averaged every $1.5 \mathrm{~nm}$ and their individual errors not shown, and, for the mixture experiment, only three out of six retrievals are shown. The averaged errors for the retrievals for each experiment are shown on the left side of each panel (red symbols; their value has no meaning). 

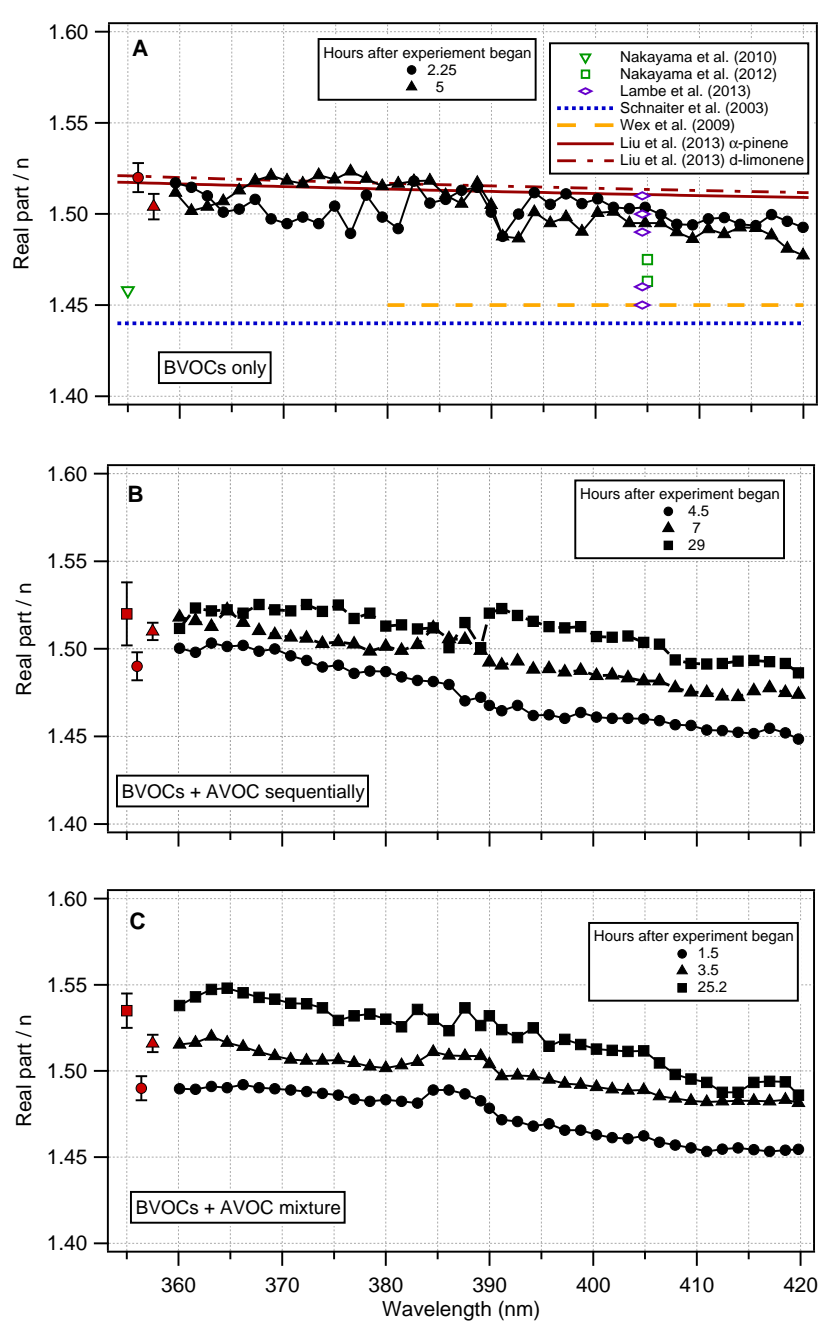

Figure 3. Change of the real part of the complex refractive index vs. wavelength as a function of time for SOA produced from (A) only a mixture of $\alpha$-pinene and limonene, compared to literature values of the real RI of $\alpha$-pinene; (B) a mixture of $\alpha$-pinene and limonene followed by the addition of $p$-xylene- $\mathrm{d}_{10} 5 \mathrm{~h}$ after; and (C) a mixture of $\alpha$-pinene, limonene, and $p$-xylene- $\mathrm{d}_{10}$ (only three retrievals are shown for clarity). The averaged error bars of the retrieved RI values are shown as red markers on the left for clarity. The average errors for the retrievals in (A) are $0.008( \pm 0.008)$ and $0.006( \pm 0.005)$ for 2.25 and $5 \mathrm{~h}$, respectively. The average errors for the retrievals in (B) are $0.005( \pm 0.008), 0.004( \pm 0.001)$, and $0.018( \pm 0.007)$ for $4.5,7$, and $29 \mathrm{~h}$, respectively. The average errors for the retrievals in $(\mathbf{C})$ are $0.007( \pm 0.006), 0.004( \pm 0.003)$, and $0.010( \pm 0.004)$ for $1.5,7$, and $25.2 \mathrm{~h}$, respectively.

Figure $3 \mathrm{a}$ shows the results for the BVOCs experiment with the ageing induced by $\mathrm{OH}$ reactions. Typical $\mathrm{NO}_{\mathrm{x}}$ levels were $<0.3 \mathrm{ppbv}$. For comparison, other studies of $\alpha$-pinene SOA ageing by ozone and $\mathrm{OH}$ reactions are also included. Figure 3a shows that there is no distinguishable change in the RI, within the calculated error, from the two retrievals taken at 2.5 and $5 \mathrm{~h}$ after the experiment began. There is only a slight spectral dependence with $n$ values varying from 1.51 $( \pm 0.01)$ at $\lambda=360 \mathrm{~nm}$ to $1.49( \pm 0.01)$ at $\lambda=420 \mathrm{~nm}$. Due to technical problems, only two retrievals could be obtained for this experiment. The results of the sequential experiment ( $p$-xylene- $\mathrm{d}_{10}$ was added $5 \mathrm{~h}$ after SOA formation from the $\alpha$-pinene and limonene mixture) are shown in Fig. 3b. For this experiment, the real part increased from a value of $n=1.50( \pm 0.01)$ to $n=1.52( \pm 0.01)$ at $\lambda=360 \mathrm{~nm}$, and from $n=1.45( \pm 0.01)$ to $n=1.49( \pm 0.02)$ at $\lambda=420$, from the first measurement at 4.5 to $29 \mathrm{~h}$ of ageing. Contrary to the BVOC experiment, there is a clearer increase in the real part. Figure $3 \mathrm{c}$ shows the results for the mixture experiment (the $\alpha$-pinene and limonene mixture and $p$-xylene- $\mathrm{d}_{10}$ were added simultaneously). Here there is an increase in the real part of the RI from 1.5 to $25.2 \mathrm{~h}$ of ageing, changing from $n=1.49( \pm 0.01)$ to $n=1.54( \pm 0.01)$ at $\lambda=360 \mathrm{~nm}$, and from $n=1.45( \pm 0.01)$ to $1.49( \pm 0.02)$ at $\lambda=420 \mathrm{~nm}$. The three experiments show a slight spectral dependence of the real part of the RI with higher values of the real part at shorter wavelengths.

\subsection{Refractive indices - literature comparison}

In the past few years, several laboratory studies have retrieved the complex refractive indices of SOA generated from biogenic and anthropogenic precursors (Schnaiter et al., 2003; Wex et al., 2009; Kim et al., 2010, 2012; LangYona et al., 2010; Cappa et al., 2011; Nakayama et al., 2012, 2013; Kim and Paulson, 2013; Lambe et al., 2013), with only a few retrieving the RIs in the near-UV spectral region. For example, for SOA generated from the ozonolysis of $\alpha$-pinene, Liu et al. (2013) found values of the real part of $n=1.517( \pm 0.003)$ and $n=1.509( \pm 0.003)$ for $\lambda=360 \mathrm{~nm}$ and $\lambda=420 \mathrm{~nm}$, respectively, using a variable-angle spectroscopic ellipsometer with initial ozone and $\alpha$-pinene concentrations of $52.2( \pm 2.2)$ ppmv and $4.0( \pm 1.4)$ ppmv, respectively. The imaginary components they found in this range were below $k<10^{-4}$. Using cavity ring down spectroscopy (CRDS), Nakayama et al. (2012) retrieved values between $n=1.463( \pm 0.019)$ and $n=1.475( \pm 0.022)$ at $\lambda=405 \mathrm{~nm}$, and Nakayama et al. (2010) found values of $n=1.458$ $( \pm 0.019)$ at $\lambda=355 \mathrm{~nm}$. The imaginary parts for both studies were found to be below 0.003. Both studies used initial concentrations of $0.1 \mathrm{ppmv}$ of $\alpha$-pinene and 1.1-2.6ppmv of ozone. Wex et al. (2009) retrieved only the real part of the RI by using a white-light optical particle spectrometer, and found a value of $n=1.45$ for the visible wavelengths. They used $\mathrm{O}_{3}$ concentrations of up $2.5 \mathrm{ppmv}$, and $\alpha$-pinene concentrations in excess of that of $\mathrm{O}_{3}$. Similarly, Schnaiter et al. (2003) determined a constant value of $n=1.44$ for $\lambda>350 \mathrm{~nm}$ by measuring the wavelength dependence of the SOA scattering and extinction. They generated the $\alpha$-pinene SOA by admixing $470 \mathrm{ppb}$ ozone, followed by the addition of $61 \mathrm{ppb} \alpha$-pinene. Using a potential aerosol mass flow tube reactor with a CRDS and a photoacoustic sensor to retrieve 


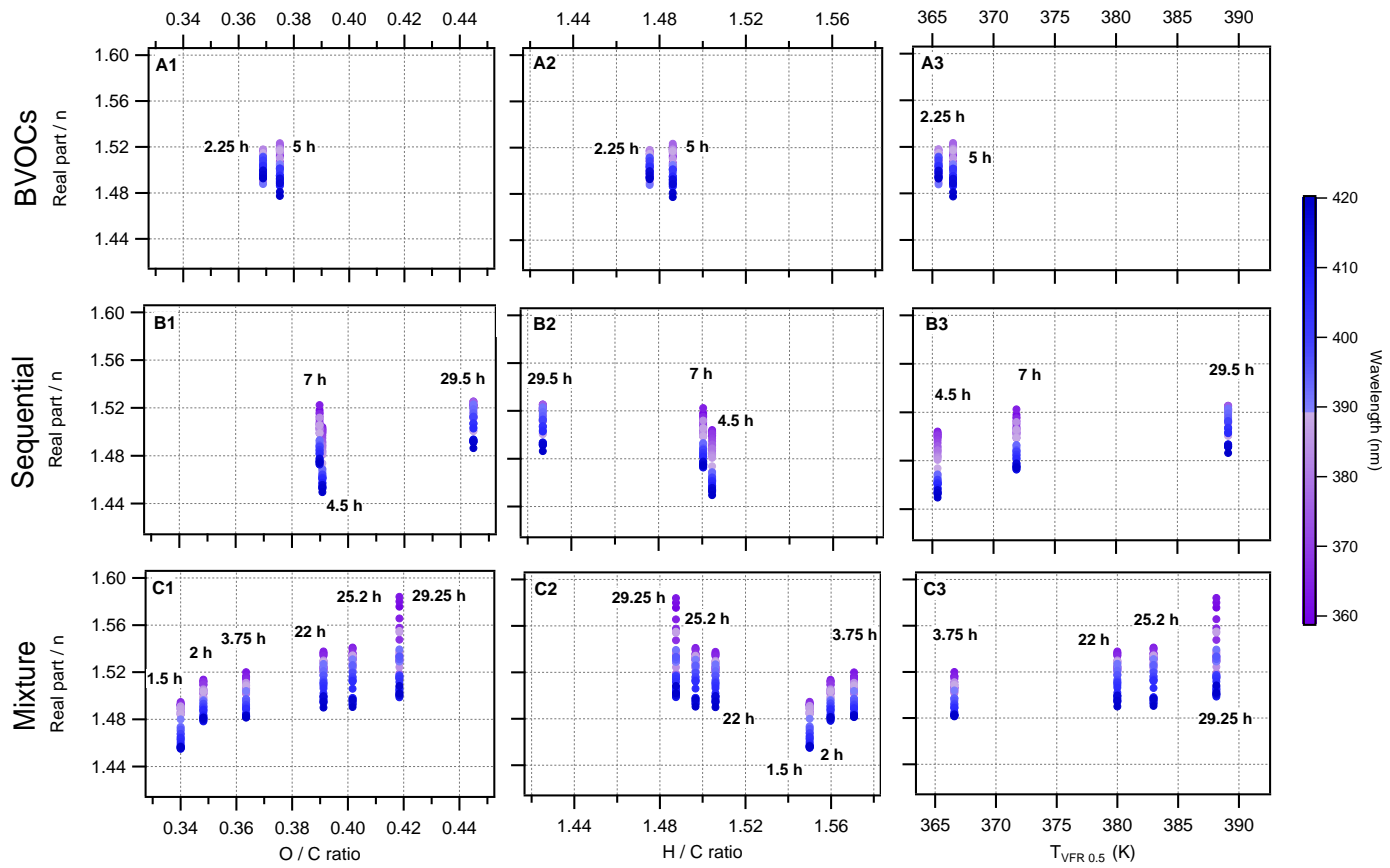

Figure 4. The change in time (given in hours, shown next to the retrieved values) for the retrieved real part of the RI as a function of $\mathrm{O} / \mathrm{C}$ ratio (panels A1, B1, and C1), H/C ratio (panels A2, B2, and C2), and $T_{\mathrm{VFR} 0.5}$ (the temperature at which the volume fraction remaining was reduced by half; panels A3, B3, and C3). The top panels - (A1), (A2) and (A3) - show the results for the SOA produced from a $1: 1$ mixture of $\alpha$-pinene and limonene. The middle panels - (B1), (B2), and (B3) - show the results for the SOA produced from the mixture of $\alpha$-pinene, limonene, and $p$-xylene- $\mathrm{d}_{10}$. The lower panels - (C1), (C2), and (C3) - show the results for the SOA produced from the sequential addition of the mixture of $\alpha$-pinene and limonene followed by $p$-xylene- $\mathrm{d}_{10}$. The color scale indicates the measured wavelength. For clarity, the error bars for the $\mathrm{O} / \mathrm{C}(31 \%), \mathrm{H} / \mathrm{C}(10 \%)$, and $T_{\mathrm{VFR} 0.5}$ are not shown. The average error for the $T_{\mathrm{VFR} 0.5}$ is $2.3 \mathrm{~K}$.

RIs, Lambe et al. (2013) found values between $n=1.51$ $( \pm 0.02)$ and $n=1.45( \pm 0.04)$ with imaginary part values of $k<0.001$ at $\lambda=405 \mathrm{~nm}$ for SOA formed by homogeneous nucleation and condensation following $\mathrm{OH}$ oxidation of $\alpha$ pinene at different oxidation levels.

For SOA formed by ozonolysis of limonene, we could only find one study that measured the RI in the UV spectral region. Liu et al. (2013) measured $n$ values between $1.520( \pm 0.003)$ and $1.512( \pm 0.003)$ and imaginary parts below $k<10^{-4}$ for wavelengths between 420 and $360 \mathrm{~nm}$. Recently, Kim and Paulson (2013) measured the real part of the RI for SOA generated from the ozonolysis of $\alpha$-pinene and limonene with and without an $\mathrm{OH}$ scavenger in a Teflon chamber using a polar nephelometer at $\lambda=532 \mathrm{~nm}$. For both SOA products, they found that the real part of the RI increased from $1.39( \pm 0.03)$ to $1.52( \pm 0.03)$ as the particles sizes grew in time (up to $4 \mathrm{~h}$ ), with no discernible effect when an $\mathrm{OH}$ scavenger was used.

\subsection{Relationship between oxidation level and refractive index}

Oxidative ageing changes the SOA's oxidation state, density, mean molecular weight, and polarizability (Katrib et al., 2005; Liu and Daum, 2008; Cappa et al., 2011; Lambe et al.,
2013). $\mathrm{O} / \mathrm{C}$ and $\mathrm{H} / \mathrm{C}$ ratios are useful metrics to measure the oxidative state of the aerosol (Ng et al., 2010). Figure 4 shows the change in the retrieved complex refractive index (real part only) for wavelengths between 360 and $420 \mathrm{~nm}$ as a function of the $\mathrm{O} / \mathrm{C}$ ratio (Fig. 4a1, $4 \mathrm{~b} 1$ and $4 \mathrm{c} 1$ ), $\mathrm{H} / \mathrm{C}$ ratio (Fig. 4a2, 4b2 and 4c2), and $T_{\mathrm{VFR} 0.5}$ (Fig. 4a3, 4b3, and $4 \mathrm{c} 3)$ as the SOA evolved with time.

For the mixture experiment it can be seen that the value of the RI increases with SOA ageing. This is correlated with the SOA increasing oxidation level (Fig. $4 \mathrm{c} 1$ ): the $\mathrm{O} / \mathrm{C}$ values increase from $\sim 0.34( \pm 0.10)$ at $1.5 \mathrm{~h}$ to $\sim 0.42( \pm 0.13)$ at $29 \mathrm{~h}$ of ageing, the $\mathrm{H} / \mathrm{C}$ ratio decreases (Fig. $4 \mathrm{c} 2$ ) from $\sim 1.55$ ( \pm 0.16$)$ to $1.49( \pm 0.15)$, and the volatility (Fig. $4 \mathrm{c} 3)$ decreases with $T_{\mathrm{VFR} 0.5}$ increasing from $\sim 366 \mathrm{~K}( \pm 2)$ up to $\sim 388 \mathrm{~K}( \pm 1)$. There is a similar trend for the sequential experiment. However, the magnitude of the increase in RI with respect to the $\mathrm{O} / \mathrm{C}$ ratio is smaller, even though the $\mathrm{O} / \mathrm{C}$ ratio increased more $(\sim 0.44)$ for approximately the same ageing time. Furthermore, the rate of change of the RI with respect to the $\mathrm{H} / \mathrm{C}$ ratio is also smaller than for the mixture experiment: the $\mathrm{H} / \mathrm{C}$ ratio decreased from around $1.50( \pm 0.15)$ to $\sim 1.45( \pm 0.15)$. There is no clear difference between the two experiments with regard to the dependence of the real part of the RI on volatility. For the BVOCs experiment it is difficult to assess a relationship with only two retrievals 
Table 2. Real parts of the RI for different $\mathrm{O} / \mathrm{C}$ ratios in this study compared with literature values.

\begin{tabular}{|c|c|c|c|c|c|c|c|c|}
\hline Real part $(n)$ of the RI & $\begin{array}{r}\mathrm{O} / \mathrm{C} \text { atomic } \\
\text { ratio }\end{array}$ & $\begin{array}{l}\text { VOC } \\
\text { (Initial conc. in ppmv) }\end{array}$ & $\begin{array}{l}\text { SOA } \\
\text { formation }\end{array}$ & $\begin{array}{r}\text { Ini. }\left[\mathrm{O}_{3}\right] \\
(\mathrm{ppmv})\end{array}$ & $\begin{array}{c}\text { Ini. }[\mathrm{OH}] \\
\left(\times 10^{10} \text { molec. } \mathrm{cm}^{-3}\right)\end{array}$ & $\begin{array}{r}\text { Exposure } \\
\text { time }\end{array}$ & $\begin{array}{l}\text { Wavelength } \\
\quad(\mathrm{nm})\end{array}$ & Reference \\
\hline $1.50( \pm 0.01)-1.49( \pm 0.01)$ & $0.37-0.38$ & $\begin{array}{l}\alpha \text {-pinene }+ \text { limonene } \\
(0.048+0.048)\end{array}$ & $\begin{array}{l}\text { ozonolysis and } \\
\text { OH oxidation }\end{array}$ & 0.2 & 0.00074 & up to $50 \mathrm{~h}$ & 405 & This work \\
\hline $1.46( \pm 0.01)-1.50( \pm 0.02)$ & $0.39-0.44$ & $\begin{array}{l}\alpha \text {-pinene }+ \text { limonene }+p \text {-xylene- } \mathrm{d}_{10}^{\mathrm{a}} \\
(0.039+0.039+0.051)\end{array}$ & $\begin{array}{l}\text { ozonolysis and } \\
\mathrm{OH} \text { oxidation }\end{array}$ & 0.2 & 0.00078 & up to $29 \mathrm{~h}$ & 405 & This work \\
\hline $1.46( \pm 0.01)-1.51( \pm 0.01)$ & $0.35-0.42$ & $\begin{array}{l}\alpha \text {-pinene }+ \text { limonene }+p \text {-xylene- } \mathrm{d}_{10} \\
(0.042+0.042+0.090)\end{array}$ & $\begin{array}{l}\text { ozonolysis and } \mathrm{OH} \\
\text { oxidation }\end{array}$ & 0.2 & 0.00080 & up to $29.5 \mathrm{~h}$ & 405 & This work \\
\hline $1.511( \pm 0.003)$ & $<0.3$ & $\begin{array}{l}\alpha \text {-pinene } \\
(4.0 \pm 1.4)^{\mathrm{b}}\end{array}$ & ozonolysis & $52.2 \pm 2.2^{\mathrm{b}}$ & Scavenger ${ }^{\mathrm{c}}$ & $\sim 38 \mathrm{~s}$ & 405 & Liu et al. (2013) \\
\hline $1.514( \pm 0.003)$ & $<0.3$ & $\begin{array}{l}\text { limonene } \\
(3.0)\end{array}$ & ozonolysis & $30 \pm 0.5$ & & & 405 & Liu et al. (2013) \\
\hline $1.51( \pm 0.02)-1.45( \pm 0.04)$ & $0.42-0.93$ & $\begin{array}{l}\alpha \text {-pinene } \\
(\mathrm{NA})\end{array}$ & $\mathrm{OH}$ oxidation & NA & $22( \pm 11)-150( \pm 20)$ & $\sim 100 \mathrm{~s}$ & 405 & Lambe et al. (2013) \\
\hline $1.66( \pm 0.04)-1.58( \pm 0.06)$ & $0.52-1.29$ & $\begin{array}{l}\text { naphthalene } \\
\text { (NA) }\end{array}$ & $\mathrm{OH}$ oxidation & NA & & & 405 & Lambe et al. (2013) \\
\hline $1.55( \pm 0.01)-1.53( \pm 0.01)$ & $0.70-1.14$ & $\begin{array}{l}\text { guaiacol } \\
(\mathrm{NA})\end{array}$ & $\mathrm{OH}$ oxidation & NA & & & 405 & Lambe et al. (2013) \\
\hline $1.54( \pm 0.01)-1.48( \pm 0.01)$ & $0.37-0.89$ & $\begin{array}{l}\text { tricycle }\left[5.2 .10^{2,6}\right] \text { decane } \\
\text { (NA) }\end{array}$ & $\mathrm{OH}$ oxidation & NA & & & 405 & Lambe et al. (2013) \\
\hline $1.449( \pm 0.030)-1.567( \pm 0.043)$ & $0.64-0.73$ & toluene (4.0) & photooxidation & NA & $\sim 27$ & up to $4 \mathrm{~h}$ & 405 & Nakayama et al. (2013) \\
\hline $1.431( \pm 0.026)-1.498( \pm 0.025)$ & $0.64-0.73$ & toluene (4.0) & photooxidation & NA & & & 532 & Nakayama et al. (2013) \\
\hline $1.475( \pm 0.022)-1.498( \pm 0.030)$ & $0.43-0.47$ & $\alpha$-pinene $(0.1)$ & ozonolysis and photooxidation & 1.1 and 2.6 & $\sim 27$ & up to $4 \mathrm{~h}$ & 405 & Nakayama et al. (2012) \\
\hline $1.476( \pm 0.021)-1.458( \pm 0.02)$ & $0.43-0.47$ & $\alpha$-pinene $(0.1)$ & ozonolysis and photooxidation & & & & 532 & Nakayama et al. (2012) \\
\hline $1.47( \pm 0.02)-1.52( \pm 0.00)$ & $0-0.35$ & squalene (NA) & $\mathrm{OH}$ oxidation & NA & 0 to $\sim 200$ & $37 \mathrm{~s}$ & 532 & Cappa et al. (2011) \\
\hline $1.47( \pm 0.02)-1.54( \pm 0.00)$ & $0.45-0.75$ & azelaic acid (NA) & OH oxidation & & & & 532 & Cappa et al. (2011) \\
\hline
\end{tabular}

${ }^{\mathrm{a}} \mathrm{p}$-xylene- $\mathrm{d}_{10}$ was added $5 \mathrm{~h}$ after; ${ }^{\mathrm{b}}$ average of four experiments; ${ }^{\mathrm{c}}$ butanol was used as an $\mathrm{OH}$ scavenger; NA: not available.

within the first $5 \mathrm{~h}$ of the experiment. There is only evidence that the RI remained constant (as seen in Fig. 3) with a small increase in the $\mathrm{O} / \mathrm{C}$ ratio, and a slight decrease in volatility with $T_{\mathrm{VFR} 0.5}$ increasing from $365.5 \mathrm{~K}( \pm 2.7)$ to $366.7 \mathrm{~K}$ (土2.6).

The relationship between optical properties and chemical composition has been previously explored. Table 2 summarizes the different studies that have related the $\mathrm{RI}$ to the $\mathrm{O} / \mathrm{C}$ ratio. Lambe et al. (2013) measured the real part of the RI at $\lambda=405 \mathrm{~nm}$ for SOA formed from the $\mathrm{OH}$ oxidation of $\alpha$ pinene, naphthalene and tricyclo-decane (anthropogenic surrogate precursors), and guaiacol (biomass burning surrogate precursor). They observed a decrease in $n$ with increase in SOA oxidation level. For $\alpha$-pinene, $\mathrm{O} / \mathrm{C}=0.42$ at the beginning of the experiment, increasing to $\mathrm{O} / \mathrm{C}=0.93$, and an RI decrease from $n=1.51( \pm 0.02)$ to 1.45 ( \pm 0.04$)$ were obtained. They also observed a slight increase in the imaginary component of the RI from $k=0$ to 0.001 ; however, these values are very low. In contrast, Cappa et al. (2011), who studied the heterogeneous $\mathrm{OH}$ oxidation of squalane (a saturated hydrocarbon) and azelaic acid (a dicarboxylic acid) particles at $\lambda=532 \mathrm{~nm}$, observed an increasing trend with similar oxidation levels $(\mathrm{O} / \mathrm{C}=0-0.35)$ compared with the ones measured in this study. They measured an increase in the real part from about $n=1.47( \pm 0.02)$ at $\mathrm{O} / \mathrm{C}=0.0$ to about $n=1.52$ at $\mathrm{O} / \mathrm{C}=0.35$ for squalene, and from $n=1.46$ to 1.55 for azelaic acid at $\mathrm{O} / \mathrm{C}$ ratios from 0.45 to 0.75 . Nakayama et al. (2013) also saw an increasing trend studying the RI of SOA generated from the photooxidation of toluene (an aromatic hydrocarbon). At $\lambda=405 \mathrm{~nm}$ the real part increased from $n=1.449( \pm 0.030)$ to $n=1.567( \pm 0.042)$, and at $\lambda=532 \mathrm{~nm}$ from $n=1.431( \pm 0.026)$ to $n=1.498( \pm 0.025)$ for $\mathrm{O} / \mathrm{C}$ values from 0.64 to 0.73 . Nakayama et al. (2012) retrieved RI values for SOA produced from the ozonoly- sis and photooxidation of $\alpha$-pinene, and found values from $n=1.463( \pm 0.019)$ to $n=1.475( \pm 0.022)$ at $\lambda=405 \mathrm{~nm}$ and $n=1.476( \pm 0.021)-1.458( \pm 0.020)$ at $\lambda=532 \mathrm{~nm}$ for $\mathrm{O} / \mathrm{C}$ ratios from 0.43 to 0.47 . Therefore, it is difficult to assess a decreasing or increasing trend from the Nakayama et al. (2012) study.

\subsection{Chemical ageing}

To help assess the chemical changes in the different SOA and compare them to literature values, Fig. 5 shows a van Krevelen diagram (van Krevelen, 1950) of the $\mathrm{H} / \mathrm{C}$ ratio as a function of the $\mathrm{O} / \mathrm{C}$ ratio. Figure 5 a shows that the $\mathrm{H} / \mathrm{C}$ ratio for the BVOC and sequential experiment show a similar behavior, the $\mathrm{H} / \mathrm{C}$ ratio remains nearly constant for the first few hours of the experiment and then decreases. For the $\mathrm{BVOC}$ experiment the $\mathrm{H} / \mathrm{C}$ ratio starts at around 1.50 and decreases to about 1.40 , and in the sequential experiment it begins at 1.51 and decreases to $\sim 1.43$. The mixture experiment, however, shows an increase of the $\mathrm{H} / \mathrm{C}$ ratio in the first few hours of the experiment, from 1.51 to 1.57 , followed by a decrease to $\sim 1.49$ at the end of the experiment.

In the evolution of the $\mathrm{O} / \mathrm{C}$ and $\mathrm{H} / \mathrm{C}$ ratios there are three distinct features: (1) the initial increase in the $\mathrm{H} / \mathrm{C}$ ratio, especially seen in the mixture experiment; (2) the increase of the $\mathrm{O} / \mathrm{C}$ ratio during daytime with the $\mathrm{H} / \mathrm{C}$ remaining almost constant; and (3) the $\mathrm{O} / \mathrm{C}$ remaining constant, even decreasing, during nighttime, whereas the $\mathrm{H} / \mathrm{C}$ decreased. The initial increase of the $\mathrm{H} / \mathrm{C}$ to $\mathrm{O} / \mathrm{C}$ ratio occurs in the phase of vigorous chemistry and particle growth at the instance ozone is added. There are two overlapping processes occurring in this stage: chemical ageing, which increases the $\mathrm{O} / \mathrm{C}$ ratio and lowers the $\mathrm{H} / \mathrm{C}$ ratio (e.g., pinic acid, multiple ketones), and fast growth by dissolution of semivolatile oxidized products, which maintains the $\mathrm{O} / \mathrm{C}$ ratio of the 


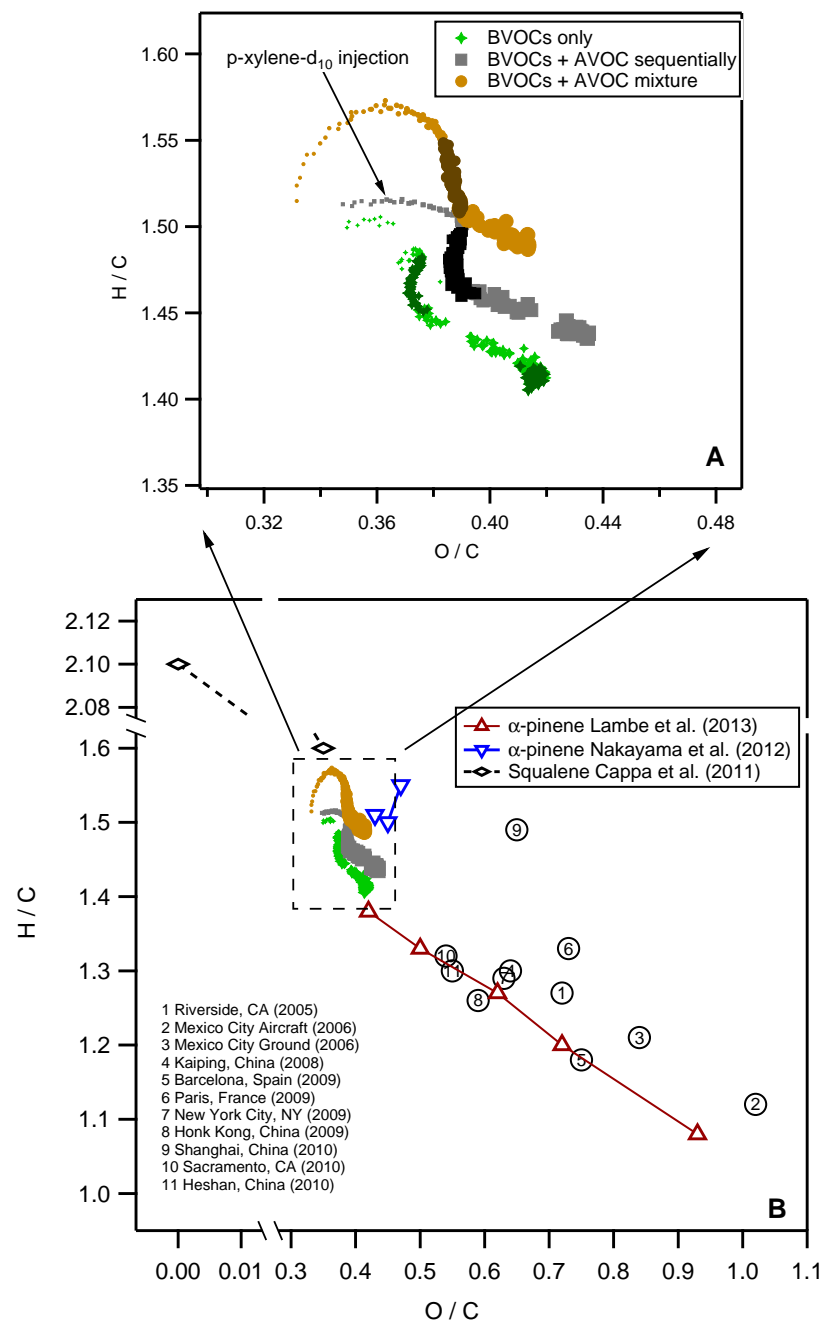

Figure 5. Van Krevelen diagram showing the ratio of $\mathrm{H} / \mathrm{C}$ to $\mathrm{O} / \mathrm{C}$ measured for the three experiments performed in this study: a mixture of $\alpha$-pinene with limonene (green diamonds); a mixture of $\alpha$-pinene with limonene with a sequential addition of $p$-xylene$\mathrm{d}_{10}$ (grey squares); and a mixture of $\alpha$-pinene, limonene, and $p$ xylene- $\mathrm{d}_{10}$ (orange circles). The change in marker size depicts time; smaller markers refer to the beginning of the experiment, and larger markers to the end. The top panel (A) shows specifically the three experiments performed in this study. The darker colors depict nighttime. In the lower panel (B), the results are compared to the lowvolatility oxygenated organic aerosol factors from HR-AMS field campaigns (numbered circles, adopted from Daumit et al., 2013), results for $\alpha$-pinene SOA from Lambe et al. (2013) (red triangles), and Nakayama et al. (2012) (blue inverted triangles), and squalene SOA from Cappa et al. (2011) (black rhombuses).

precursors (e.g., pinonic acid, pinonealdehyde, hydroperoxides), but has an increasing effect on the $\mathrm{H} / \mathrm{C}$ ratio. The strongest effect in the initial increase of the $\mathrm{H} / \mathrm{C}$ ratio, with the simultaneous $\mathrm{O} / \mathrm{C}$ increase, is clearly seen in the mixture experiment. This may be due to the oxidation conditions, or it could reflect the influence of $p$-xylene- $\mathrm{d}_{10}$. The difference is not clear, as the three experiments began with similar temperatures, $\mathrm{RH}$ values, pressure, and $\mathrm{OH}$ concentrations (Fig. 2). However, the initial ozone concentration and solar radiation exposure were lower for the mixture experiment than for the other two experiments.

Following this initial stage, the mixtures are photochemical aged, with an $\mathrm{OH}$ concentration of about $2-3 \times 10^{6}$ molecules $\mathrm{cm}^{-3}$ (see Fig. 2 middle panels) for the three experiments. Here there are slight differences in the $\mathrm{O} / \mathrm{C}$ values between the BVOC and sequential experiment. This might be caused by either the addition of $p$-xylene- $\mathrm{d}_{10} 5 \mathrm{~h}$ after the insertion of the $\alpha$-pinene-limonene mixture or the specific oxidation conditions. However, there were no significant differences between the experimental initial conditions, neither the meteorological conditions nor the VOC and $\mathrm{O}_{3}$ concentrations.

During the night, the $\mathrm{O} / \mathrm{C}$ ratio remained constant, showing a slight decrease in the BVOC and sequential experiments, whereas the $\mathrm{H} / \mathrm{C}$ ratio decreased. The slight decrease of $\mathrm{O} / \mathrm{C}$ overnight might be due to reactions in the particulate phase (e.g oligomerization). The observed decrease in the $\mathrm{H} / \mathrm{C}$ ratio during the night is probably caused by the dilution flow into the chamber which, depletes the gas phase, including semivolatile oxidized compounds, leading to their evaporation. The excess of semivolatiles, caused by the high initial load of monoterpenes, ceases at the end of the night and onset of the next day. This is seen by the simultaneous decrease of $\mathrm{H} / \mathrm{C}$ and $\mathrm{O} / \mathrm{C}$; at this stage the molecules were converted to higher oxidized generations by $\mathrm{OH}$ reactions during the second day.

\section{Discussion}

By comparing the $\mathrm{H} / \mathrm{C}$ and $\mathrm{O} / \mathrm{C}$ ratios measured in this study to values measured in different cities around the world (Fig. 5b), it is clear that the SOA in this study is less oxidized. The fact that the SOA is not as oxidized may explain the lack of absorption observed, though Nakayama et al. (2012) measured similar values of the $\mathrm{H} / \mathrm{C}$ and $\mathrm{O} / \mathrm{C}$ ratios and also found negligible absorption. Cappa et al. (2011) with higher values of the $\mathrm{H} / \mathrm{C}$ ratio and lower values of the $\mathrm{O} / \mathrm{C}$ ratio assumed purely scattering particles. Lambe et al. (2013), who were able to age BSOA formed from $\mathrm{OH}$ oxidation of $\alpha$-pinene (Fig. $5 \mathrm{~b}$, red triangles) up to $\mathrm{O} / \mathrm{C}=0.93$ and $\mathrm{H} / \mathrm{C}=1.1$, only saw an increase in the imaginary component from $k=0$ to $k=0.001$. In addition, for ASOA, formed from the $\mathrm{OH}$ oxidation of naphthalene, they saw an increase in $k$ up to 0.0035 for $\mathrm{O} / \mathrm{C}=1.3$ and $\mathrm{H} / \mathrm{C}=0.84$. Only Nakayama et al. (2013) saw slightly higher absorption at $\mathrm{O} / \mathrm{C}$ ratios between 0.64 and 0.73 , but for SOA generated from the photooxidation of toluene at different $\mathrm{NO}_{\mathrm{x}}$ levels, with measured $k$ values between $0.0018( \pm 0.0014)$ and $0.0072( \pm 0.0010)$ at $\lambda=405 \mathrm{~nm}$. 
The values of the real part retrieved in this study are within the values reported in the literature; however, there is a significant span in the real part, from $n=1.44$ to $n=1.58$, among all the studies (for example, see the values at $\lambda=405 \mathrm{~nm}$ in Table 2 and Fig. 3). The differences in RI values suggest differences in the SOA chemical composition, which can arise from several different factors: for example, the initial VOC and its concentration, oxidant levels, formation temperature and relative humidity, the residence times in either the flow tubes or chamber experiments, and the experimental procedure. The differences in the SOA chemical composition from different initial VOC concentration (which will directly influence the initial mass concentration) seems unlikely; on the one hand, Bateman et al. (2011) and Walser et al. (2008) demonstrated that the composition of limonene $+\mathrm{O}_{3}$ SOA formed in either a smog chamber with low mixing ratios $(<0.1 \mathrm{ppmv})$ or a flow tube with significantly higher $(\sim 10 \mathrm{ppmv})$ mixing ratios is similar. On the other hand, Shilling et al. (2009) saw small composition differences of $\alpha$-pinene SOA when mass concentrations were above $20 \mu \mathrm{g} \mathrm{m}^{-3}$. All the studies reported here used mass concentration greater than $20 \mu \mathrm{g} \mathrm{m}^{-3}$; hence, no significant differences in the RIs would be expected. The oxidation level may perhaps explain the differences; however, there are no clear trends from the available studies. For example, Lambe et al. (2013) showed that the real part of the RI decreases with increasing oxidation, and Liu et al. (2013) mentioned that the low oxidation level of their SOA (from Shilling et al. 2009, this would correspond to $\mathrm{O} / \mathrm{C}<0.3$ as the mass loading was $>140 \mu \mathrm{g} \mathrm{m}^{-3}$ ) could possibly explain why their measured $n$ values are higher than the other reported values. In contrast, Cappa et al. (2011) and Nakayama et al. (2013) observed the opposite trend, i.e., an increase in the real part with increasing $\mathrm{O} / \mathrm{C}$ ratio, which is the same trend observed in this study. The initial increase in the real part of the RI in this study might be explained by the change in the SOA density. One form of the Lorentz-Lorentz relation associates the RI with the mean polarizability $(\alpha)$, the molecular weight (MW), and the density of the particle:

$$
\frac{\left(n^{2}-1\right)}{\left(n^{2}+2\right)}=\frac{\alpha \cdot \rho}{3 \cdot \mathrm{MW}} \text {. }
$$

Furthermore, Liu and Daum (2008) showed that the real part of the refractive index increases with mass density, and Katrib et al. (2005) showed that the density of layers of oleic acid increases as the oxygen content increases. Figure 6a shows the change in SOA density with time for the three experiments; only values up to $15 \mathrm{~h}$ after the experiments began are shown, and Fig. 6b shows the change in RI vs. density. Figure $6 \mathrm{~b}$ clearly shows the concomitant increase in the real part of the RI and density for the sequential and mixture experiments, while Fig. 6a demonstrates the $\rho$ increase for all experiments and the distinct differences in change of density with time among the three experiments. For example,
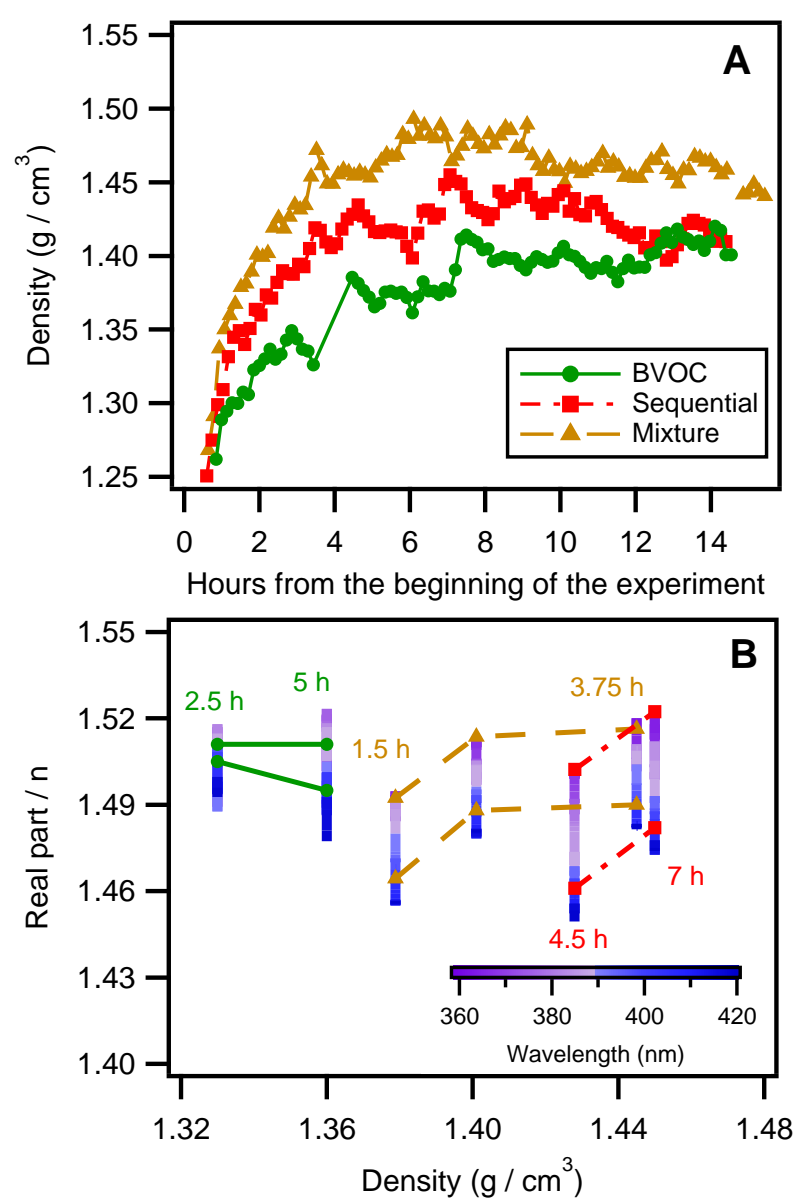

Figure 6. (A) Time series of the density measured for the BVOC (green circles), the sequential (red squares), and the mixture (orange triangles) experiment. (B) The change in time of the real part of the RI vs. density for each experiment performed. The color bars show the span in the RI for the wavelengths measured; the time span between the measurements is written above (for the BVOC and sequential experiments) and below (the mixture experiment) each set of measurements.

the BVOC experiment shows the lowest values up until about $14 \mathrm{~h}$ after the beginning of the experiment, when it acquires the same values as the sequential experiment, while the mixture experiment shows consistently higher values than the BVOC and sequential experiments. The increase in $\rho$ seen in Fig. $6 \mathrm{~b}$ can help explain the increase in the real part of the RI seen in the mixture (Fig. 4c1) and sequential experiments (Fig. 4b1) and, assuming the trends between the experiments remain the same up to $30 \mathrm{~h}$ after the experiments began, the greater increase in the RI in the mixture experiment. Figure $6 \mathrm{~b}$ also demonstrates the influence of the MW due to the addition of $p$-xylene- $\mathrm{d}_{10}$, as the initial RI for the BVOC experiment is higher than the sequential and mixture experiments.

The increase in the density from 4.5 to $7 \mathrm{~h}$ after the beginning of the experiment seen in the sequential experiment 
occurred practically under dark conditions (see Fig. 2 $j\left(\mathrm{NO}_{2}\right)$ values). This might be attributed to a combination of a few processes: condensation of ozonolysis products, oligomerization, and evaporation of more volatile material from the particles. Between 4.5 and $7 \mathrm{~h}$ the photochemistry and oxidation of $p$-xylene-d10 stopped due to the lack of sunlight, but $\mathrm{O}_{3}$ and some monoterpenes were still present. Furthermore, the $\mathrm{O} / \mathrm{C}$ ratio slightly decreased in that period. This indicates that either ozonolysis products with smaller $\mathrm{O} / \mathrm{C}$ ratios than the products from photochemistry condensed onto the SOA or that non-oxidative liquid-phase processes of glyoxal-like structures (i.e., oligomerization) took place at the same time, such as condensation reactions that can lower the $\mathrm{O} / \mathrm{C}$ ratio but still compact the particles.

\section{Atmospheric relevance and implications}

To assess the atmospheric relevance of the SOA measured in this study Fig. 7 shows the $f_{44}$ vs. $f_{43}$ ratio measured for the three experiments presented here. $\mathrm{Ng}$ et al. (2010) suggested that the ratio $f_{44} / f_{43}$ can be used to estimate the degree of oxidation and volatility, within the oxygenated organic aerosol (OOA) components; they defined the less oxidized components (lower $f_{44}$ ) as semivolatile OOA and the more oxidized (higher $f_{44}$ ) as low-volatility OOA. In other words, a low $f_{44} / f_{43}$ value can be used as an indication of semivolatile OOA and a higher $f_{44} / f_{43}$ value indicates lower volatility OOA. The triangle in the insert in Fig. 7 shows the area proposed by $\mathrm{Ng}$ et al. (2010) which encompasses the majority of the OOA measured in the field. It can be seen that the SOAs studied here fall within the lower right section of the triangle and are overall similar, suggesting that the SOA formed in these experiments may be semivolatile. Furthermore, Fig. 7 shows that, for all three experiments, the $f_{44}$ signal increases and $f_{43}$ decreases as the SOA age, from approximately $f_{44}=0.05$ to $\sim 0.08$ to 0.10 and from $f_{43}=0.16$ down to $\sim 0.12$, confirming that the SOA became less volatile with time, as shown in Fig. $4 \mathrm{~b} 3$ and $4 \mathrm{c} 3$. Moreover, whereas there is no distinguishable difference in the $f_{44} / f_{43}$ signals between the BVOCs and sequential experiment, the mixture experiment has a lower $f_{43}$ signal at a given $f_{44}$, suggesting that BSOA have fewer volatile components $\left(f_{43}\right)$ than ABSOA at the same degree of oxidation $\left(f_{44}\right)$. It further suggests that the interaction of $p$-xylene- $\mathrm{d}_{10}$ with $\alpha$-pinene and limonene in the mixture experiment can change the chemical and volatility properties of the ABSOA formed in comparison to the properties of BSOA, whereas the interaction of $p$-xylene- $\mathrm{d}_{10}$ with BSOA in the sequential experiment does not significantly alter the chemical and volatility properties. However, overall the mass spectral characteristics do not show enough differences to distinguish the influence of anthropogenic VOCs on the oxygenated organic aerosol. Figure 7 also shows that even though the BSOA and ABSOA were not oxidized significantly and the initial

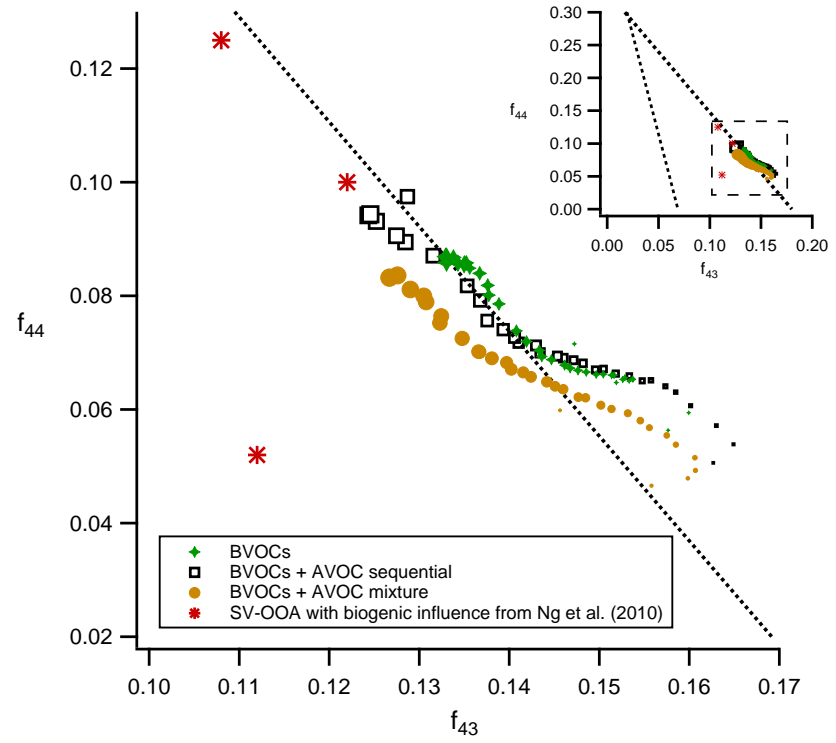

Figure 7. $f_{44}$ vs. $f_{43}$ for the SOA produced from the mixture of $\alpha$-pinene and limonene (green diamonds); from the sequential addition of the mixture of $\alpha$-pinene and limonene followed by $p$-xylene$\mathrm{d}_{10}$ (black squares); and from the mixture of $\alpha$-pinene, limonene, and $p$-xylene- $\mathrm{d}_{10}$ (orange circles). The change in size of the markers depicts time; smaller markers refer to the beginning of the experiment, and larger markers to the end. The insert shows the total triangular area (dotted lines) that represents the common values of ambient oxygenated organic aerosol components, adapted from $\mathrm{Ng}$ et al. (2010).

BVOC and AVOC concentrations are higher than atmospherically relevant concentrations, the oxidation and volatility levels of the SOA fall within an atmospherically relevant range, specifically at the edge of large $f_{43}$; in other words, there is large influence of semivolatiles.

\section{Conclusions}

We have measured the evolution of the complex refractive index in the UV spectral region, between 360 and $420 \mathrm{~nm}$, of BSOA and ABSOA formed from three different mixtures of biogenic (a mixture of $\alpha$-pinene and limonene) and anthropogenic $\left(p\right.$-xylene- $\left.\mathrm{d}_{10}\right)$ VOCs at low $\mathrm{NO}_{\mathrm{x}}$ levels. Additionally, we have explored the relationship of the oxidation level, $\mathrm{H} / \mathrm{C}$, and volatility with the RI as the SOA ages due to $\mathrm{OH}$ oxidation in the outdoor atmospheric simulation chamber SAPHIR over a diurnal cycle. One experiment consisted of pure BSOA produced from a $1: 1$ mixture of $\alpha$-pinene and limonene; the other two experiments consisted of ABSOA, one with the ABSOA produced from the sequential addition of a 1:1 mixture of $\alpha$-pinene and limonene followed by $p$ xylene- $\mathrm{d}_{10}$, and the other with the ABSOA produced from a mixture of $\alpha$-pinene, limonene and $p$-xylene- $\mathrm{d}_{10}$. We found an increase in the real part of the RI with ABSOA ageing, and 
no detectable absorption in any of the experiments. Furthermore, we observed a correlation between the increase in the real part of the $\mathrm{RI}$ and the increase of the $\mathrm{O} / \mathrm{C}$ ratio, with a greater increase in RI when the ABSOA is produced from the mixture of BVOCs and AVOC than from the sequential addition of the VOCs after approximately the same ageing time. This suggests the interaction of BVOCs and AVOCs can make the ABSOA a more scattering aerosol. The increase in the real part points to the fact that it can be associated with an increase in the aerosol density. On the other hand, we only have RI retrievals from up to $5 \mathrm{~h}$ of ageing for the BSOA and could not assess how much the real part increases, if at all, over a diurnal cycle. We also observed differences in the volatility and the $\mathrm{H} / \mathrm{C}$ ratio between the BSOA and the ABSOA. From analyzing the $f_{44}$ vs. $f_{43}$ ratios measured for the three experiments, all three types of SOA can be considered semivolatile oxygenated organic aerosols, and it is suggested that the interaction of AVOC and BVOC can form ABSOA with different chemical and volatility properties than pure BSOA of BSOA that interacts with AVOC. A caveat with respect to generalization of the results obtained in this study is that the SOA measured is less oxidized than SOA measured in different cities around the world. The $\mathrm{O} / \mathrm{C}$ values in the three experiments ranged from $\sim 0.35$ to 0.44 , whereas the ones measured in the field are between 0.54 and 1.02 .

The results from this study are representative of clean conditions due to the low- $\mathrm{NO}_{\mathrm{x}}$ conditions used. Furthermore, they demonstrate that the optical properties of SOA are influenced by the interaction of BVOCs and AVOCs, are in continuous evolution, and the magnitude of their change depends explicitly on the formation mechanism of the SOA.

Acknowledgements. This study was partially supported by the German-Israeli Foundation for Scientific Research and Development, research grant no. 1136-26.8/2011, by the EUROCHAMP2 transnational access activity E2-2012-04-22-0072, and by FP7ENV-2010-265148-PEGASOS. J. M. Flores is supported by a research grant from the Jinich Postdoctoral Fellowship. We thank the SAPHIR team, especially F. Rohrer, B. Bohn, R. Häseler, M. Kaminski, A. Lutz, and I.-H. Acir, for providing helpful data and supporting our measurements. We also thank S. S. Brown and R. Washenfelder for helpful discussions and support with the optical system.

Edited by: B. Ervens

\section{References}

Abo Riziq, A., Erlick, C., Dinar, E., and Rudich, Y.: Optical properties of absorbing and non-absorbing aerosols retrieved by cavity ring down (CRD) spectroscopy, Atmos. Chem. Phys., 7, 15231536, doi:10.5194/acp-7-1523-2007, 2007.

Aiken, A. C., DeCarlo, P. F., and Jimenez, J. L.: Elemental Analysis of Organic Species with Electron Ionization High-Resolution Mass Spectrometry, Anal. Chem., 79, 8350-8358, 2007.
Aiken, A. C., DeCarlo, P. F., Kroll, J. H., Worsnop, D. R., Huffman, J. A., Docherty, K. S., Ulbrich, I. M., Mohr, C., Kimmel, J. R., Sueper, D., Sun, Y., Zhang, Q., Trimborn, A., Northway, M., Ziemann, P. J., Canagaratna, M. R., Onasch, T. B., Alfarra, M. R., Prevot, A. S. H., Dommen, J., Duplissy, J., Metzger, A., Baltensperger, U., and Jimenez, J. L.: O/C and OM/OC Ratios of Primary, Secondary, and Ambient Organic Aerosols with HighResolution Time-of-Flight Aerosol Mass Spectrometry, Environ. Sci. Technol., 42, 4478-4485, 2008.

Allan, J. D., Delia, A. E., Coe, H., Bower, K. N., Alfarra, M. R., Jimenez, J. L., Middlebrook, A. M., Drewnick, F., Onasch, T. B., Canagaratna, M. R., Jayne, J. T., and Worsnop, D. R.: A generalised method for the extraction of chemically resolved mass spectra from Aerodyne aerosol mass spectrometer data, J. Aerosol Sci., 35, 909-922, 2004.

Andreae, M. O. and Gelencsér, A.: Black carbon or brown carbon? The nature of light-absorbing carbonaceous aerosols, Atmos. Chem. Phys., 6, 3131-3148, doi:10.5194/acp-6-3131-2006, 2006.

Andreae, M. O. and Ramanathan, V.: Climate's Dark Forcings, Science, 340, 280-281, 2013.

Bahadur, R., Praveen, P. S., Xu, Y., and Ramanathan, V.: Solar absorption by elemental and brown carbon determined from spectral observations, P. Natl. Acad. Sci. USA, 109, 17366-17371, 2012.

Bateman, A. P., Nizkorodov, S. A., Laskin, J., and Laskin, A.: Photolytic processing of secondary organic aerosols dissolved in cloud droplets, Phys. Chem. Chem. Phys., 13, 12199-12212, 2011.

Bluvshtein, N., Flores, J. M., Riziq, A. A., and Rudich, Y.: An Approach for Faster Retrieval of Aerosols' Complex Refractive Index Using Cavity Ring-Down Spectroscopy, Aerosol Sci. Tech., 46, 1140-1150, 2012.

Bohn, B., Rohrer, F., Brauers, T., and Wahner, A.: Actinometric measurements of $\mathrm{NO}_{2}$ photolysis frequencies in the atmosphere simulation chamber SAPHIR, Atmos. Chem. Phys., 5, 493-503, doi:10.5194/acp-5-493-2005, 2005.

Bond, T. C., Doherty, S. J., Fahey, D. W., Forster, P. M., Berntsen, T., DeAngelo, B. J., Flanner, M. G., Ghan, S., Kärcher, B., Koch, D., Kinne, S., Kondo, Y., Quinn, P. K., Sarofim, M. C., Schultz, M. G., Schulz, M., Venkataraman, C., Zhang, H., Zhang, S., Bellouin, N., Guttikunda, S. K., Hopke, P. K., Jacobson, M. Z., Kaiser, J. W., Klimont, Z., Lohmann, U., Schwarz, J. P., Shindell, D., Storelvmo, T., Warren, S. G., and Zender, C. S.: Bounding the role of black carbon in the climate system: A scientific assessment, J. Geophys. Res.-Atmos., 118, 5380-5552, 2013.

Cappa, C. D., Che, D. L., Kessler, S. H., Kroll, J. H., and Wilson, K. R.: Variations in organic aerosol optical and hygroscopic properties upon heterogeneous OH oxidation, J. Geophys. Res.-Atmos., 116, D15204, doi:10.1029/2011jd015918, 2011.

Cappa, C. D., Onasch, T. B., Massoli, P., Worsnop, D. R., Bates, T. S., Cross, E. S., Davidovits, P., Hakala, J., Hayden, K. L., Jobson, B. T., Kolesar, K. R., Lack, D. A., Lerner, B. M., Li, S.-M., Mellon, D., Nuaaman, I., Olfert, J. S., Petäjä, T., Quinn, P. K., Song, C., Subramanian, R., Williams, E. J., and Zaveri, R. A.: Radiative Absorption Enhancements Due to the Mixing State of Atmospheric Black Carbon, Science, 337, 1078-1081, 2012. 
Chung, C. E., Ramanathan, V., and Decremer, D.: Observationally constrained estimates of carbonaceous aerosol radiative forcing, P. Natl. Acad. Sci. USA, 109, 11624-11629, 2012.

Daumit, K. E., Kessler, S. H., and Kroll, J. H.: Average chemical properties and potential formation pathways of highly oxidized organic aerosol, Faraday Discuss., 165, 181-202, 2013.

DeCarlo, P. F., Slowik, J. G., Worsnop, D. R., Davidovits, P., and Jimenez, J. L.: Particle Morphology and Density Characterization by Combined Mobility and Aerodynamic Diameter Measurements. Part 1: Theory, Aerosol Sci. Tech., 38, 1185-1205, 10.1080/027868290903907, 2004

DeCarlo, P. F., Kimmel, J. R., Trimborn, A., Northway, M. J., Jayne, J. T., Aiken, A. C., Gonin, M., Fuhrer, K., Horvath, T., Docherty, K. S., Worsnop, D. R., and Jimenez, J. L.: Field-Deployable, High-Resolution, Time-of-Flight Aerosol Mass Spectrometer, Anal. Chem., 78, 8281-8289, 2006.

Emanuelsson, E. U., Hallquist, M., Kristensen, K., Glasius, M., Bohn, B., Fuchs, H., Kammer, B., Kiendler-Scharr, A., Nehr, S., Rubach, F., Tillmann, R., Wahner, A., Wu, H.-C., and Mentel, Th. F.: Formation of anthropogenic secondary organic aerosol (SOA) and its influence on biogenic SOA properties, Atmos. Chem. Phys., 13, 2837-2855, doi:10.5194/acp-13-2837-2013, 2013a.

Emanuelsson, E. U., Watne, Å. K., Lutz, A., Ljungström, E., and Hallquist, M.: Influence of Humidity, Temperature, and Radicals on the Formation and Thermal Properties of Secondary Organic Aerosol (SOA) from Ozonolysis of $\beta$-Pinene, J. Phys. Chem. A, 117, 10346-10358, 2013b.

Feng, Y., Ramanathan, V., and Kotamarthi, V. R.: Brown carbon: a significant atmospheric absorber of solar radiation?, Atmos. Chem. Phys., 13, 8607-8621, doi:10.5194/acp-13-8607-2013, 2013.

Fuchs, H., Dorn, H.-P., Bachner, M., Bohn, B., Brauers, T., Gomm, S., Hofzumahaus, A., Holland, F., Nehr, S., Rohrer, F., Tillmann, R., and Wahner, A.: Comparison of $\mathrm{OH}$ concentration measurements by DOAS and LIF during SAPHIR chamber experiments at high $\mathrm{OH}$ reactivity and low NO concentration, Atmos. Meas. Tech., 5, 1611-1626, doi:10.5194/amt-5-1611-2012, 2012.

Glasius, M., la Cour, A., and Lohse, C.: Fossil and nonfossil carbon in fine particulate matter: A study of five European cities, J. Geophys. Res.-Atmos., 116, D11302, doi:10.1029/2011jd015646, 2011.

Hallquist, M., Wenger, J. C., Baltensperger, U., Rudich, Y., Simpson, D., Claeys, M., Dommen, J., Donahue, N. M., George, C., Goldstein, A. H., Hamilton, J. F., Herrmann, H., Hoffmann, T., Iinuma, Y., Jang, M., Jenkin, M. E., Jimenez, J. L., Kiendler-Scharr, A., Maenhaut, W., McFiggans, G., Mentel, Th. F., Monod, A., Prévôt, A. S. H., Seinfeld, J. H., Surratt, J. D., Szmigielski, R., and Wildt, J.: The formation, properties and impact of secondary organic aerosol: current and emerging issues, Atmos. Chem. Phys., 9, 5155-5236, doi:10.5194/acp-9-51552009, 2009.

Hildebrandt, L., Henry, K. M., Kroll, J. H., Worsnop, D. R., Pandis, S. N., and Donahue, N. M.: Evaluating the Mixing of Organic Aerosol Components Using High-Resolution Aerosol Mass Spectrometry, Environ. Sci. Technol., 45, 6329-6335, 2011.

Hoyle, C. R., Boy, M., Donahue, N. M., Fry, J. L., Glasius, M., Guenther, A., Hallar, A. G., Huff Hartz, K., Petters, M. D., Petäjä, T., Rosenoern, T., and Sullivan, A. P.: A review of the anthro- pogenic influence on biogenic secondary organic aerosol, Atmos. Chem. Phys., 11, 321-343, doi:10.5194/acp-11-321-2011, 2011.

Jonsson, Å. M., Hallquist, M., and Saathoff, H.: Volatility of secondary organic aerosols from the ozone initiated oxidation of pinene and limonene, J. Aerosol Sci., 38, 843-852, 2007.

Jordan, A., Haidacher, S., Hanel, G., Hartungen, E., Märk, L., Seehauser, H., Schottkowsky, R., Sulzer, P., and Märk, T. D.: A high resolution and high sensitivity proton-transfer-reaction time-offlight mass spectrometer (PTR-TOF-MS), Int. J. Mass Spectrom., 286, 122-128, 2009.

Katrib, Y., Martin, S. T., Rudich, Y., Davidovits, P., Jayne, J. T., and Worsnop, D. R.: Density changes of aerosol particles as a result of chemical reaction, Atmos. Chem. Phys., 5, 275-291, doi:10.5194/acp-5-275-2005, 2005.

Kautzman, K. E., Surratt, J. D., Chan, M. N., Chan, A. W. H., Hersey, S. P., Chhabra, P. S., Dalleska, N. F., Wennberg, P. O., Flagan, R. C., and Seinfeld, J. H.: Chemical Composition of Gasand Aerosol-Phase Products from the Photooxidation of Naphthalene, J. Phys. Chem. A, 114, 913-934, 2010.

Kim, H. and Paulson, S. E.: Real refractive indices and volatility of secondary organic aerosol generated from photooxidation and ozonolysis of limonene, $\alpha$-pinene and toluene, Atmos. Chem. Phys., 13, 7711-7723, doi:10.5194/acp-13-7711-2013, 2013.

Kim, H., Barkey, B., and Paulson, S. E.: Real refractive indices of $\alpha$ and $\beta$-pinene and toluene secondary organic aerosols generated from ozonolysis and photo-oxidation, J. Geophys. Res.-Atmos., 115, D24212, doi:10.1029/2010jd014549, 2010.

Kim, H., Barkey, B., and Paulson, S. E.: Real Refractive Indices and Formation Yields of Secondary Organic Aerosol Generated from Photooxidation of Limonene and $\alpha$-Pinene: The Effect of the HC/NO $\mathrm{N}_{\mathrm{x}}$ Ratio, J. Phys. Chem. A, 116, 6059-6067, 2012.

Kirchstetter, T. W. and Thatcher, T. L.: Contribution of organic carbon to wood smoke particulate matter absorption of solar radiation, Atmos. Chem. Phys., 12, 6067-6072, doi:10.5194/acp-126067-2012, 2012.

Koren, I., Martins, J. V., Remer, L. A., and Afargan, H.: Smoke Invigoration Versus Inhibition of Clouds over the Amazon, Science, 321, 946-949, doi:10.1126/science.1159185, 2008.

Lack, D. A., Lovejoy, E. R., Baynard, T., Pettersson, A., and Ravishankara, A. R.: Aerosol Absorption Measurement using Photoacoustic Spectroscopy: Sensitivity, Calibration, and Uncertainty Developments, Aerosol Sci. Tech., 40, 697-708, 2006.

Lambe, A. T., Cappa, C. D., Massoli, P., Onasch, T. B., Forestieri, S. D., Martin, A. T., Cummings, M. J., Croasdale, D. R., Brune, W. H., Worsnop, D. R., and Davidovits, P.: Relationship between Oxidation Level and Optical Properties of Secondary Organic Aerosol, Environ. Sci. Technol., 47, 6349-6357, 2013.

Lang-Yona, N., Rudich, Y., Segre, E., Dinar, E., and Abo-Riziq, A.: Complex Refractive Indices of Aerosols Retrieved by Continuous Wave-Cavity Ring Down Aerosol Spectrometer, Anal. Chem., 81, 1762-1769, 2009.

Lang-Yona, N., Rudich, Y., Mentel, Th. F., Bohne, A., Buchholz, A., Kiendler-Scharr, A., Kleist, E., Spindler, C., Tillmann, R., and Wildt, J.: The chemical and microphysical properties of secondary organic aerosols from Holm Oak emissions, Atmos. Chem. Phys., 10, 7253-7265, doi:10.5194/acp-10-7253-2010, 2010.

Liu, P., Zhang, Y., and Martin, S. T.: Complex Refractive Indices of Thin Films of Secondary Organic Materials by Spectroscopic 
Ellipsometry from 220 to $1200 \mathrm{~nm}$, Environ. Sci. Technol., 47, 13594-13601, 2013.

Liu, Y. and Daum, P. H.: Relationship of refractive index to mass density and self-consistency of mixing rules for multicomponent mixtures like ambient aerosols, J. Aerosol Sci., 39, 974-986, 2008

Miles, R. E. H., Rudic, S., Orr-Ewing, A. J., and Reid, J. P.: Measurements of the wavelength dependent extinction of aerosols by cavity ring down spectroscopy, Phys. Chem. Chem. Phys., 12, 3914-3920, 2010.

Michel Flores, J., Bar-Or, R. Z., Bluvshtein, N., Abo-Riziq, A., Kostinski, A., Borrmann, S., Koren, I., Koren, I., and Rudich, Y.: Absorbing aerosols at high relative humidity: linking hygroscopic growth to optical properties, Atmos. Chem. Phys., 12, 5511-5521, doi:10.5194/acp-12-5511-2012, 2012.

Nakayama, T., Matsumi, Y., Sato, K., Imamura, T., Yamazaki, A., and Uchiyama, A.: Laboratory studies on optical properties of secondary organic aerosols generated during the photooxidation of toluene and the ozonolysis of $\alpha$-pinene, J. Geophys. Res.Atmos., 115, D24204, doi:10.1029/2010jd014387, 2010.

Nakayama, T., Sato, K., Matsumi, Y., Imamura, T., Yamazaki, A., and Uchiyama, A.: Wavelength Dependence of Refractive Index of Secondary Organic Aerosols Generated during the Ozonolysis and Photooxidation of alpha-Pinene, Sola, 8, 119-123, doi:10.2151/sola.2012-030, 2012.

Nakayama, T., Sato, K., Matsumi, Y., Imamura, T., Yamazaki, A., and Uchiyama, A.: Wavelength and $\mathrm{NO}_{\mathrm{x}}$ dependent complex refractive index of SOAs generated from the photooxidation of toluene, Atmos. Chem. Phys., 13, 531-545, doi:10.5194/acp-13531-2013, 2013.

Ng, N. L., Canagaratna, M. R., Zhang, Q., Jimenez, J. L., Tian, J., Ulbrich, I. M., Kroll, J. H., Docherty, K. S., Chhabra, P. S., Bahreini, R., Murphy, S. M., Seinfeld, J. H., Hildebrandt, L., Donahue, N. M., DeCarlo, P. F., Lanz, V. A., Prévôt, A. S. H., Dinar, E., Rudich, Y., and Worsnop, D. R.: Organic aerosol components observed in Northern Hemispheric datasets from Aerosol Mass Spectrometry, Atmos. Chem. Phys., 10, 46254641, doi:10.5194/acp-10-4625-2010, 2010.

Ofner, J., Krüger, H.-U., Grothe, H., Schmitt-Kopplin, P., Whitmore, K., and Zetzsch, C.: Physico-chemical characterization of SOA derived from catechol and guaiacol - a model substance for the aromatic fraction of atmospheric HULIS, Atmos. Chem. Phys., 11, 1-15, doi:10.5194/acp-11-1-2011, 2011.

Park, R. J., Kim, M. J., Jeong, J. I., Youn, D., and Kim, S.: A contribution of brown carbon aerosol to the aerosol light absorption and its radiative forcing in East Asia, Atmos. Environ., 44, 14141421, 2010.

Pettersson, A., Lovejoy, E. R., Brock, C. A., Brown, S. S., and Ravishankara, A. R.: Measurement of aerosol optical extinction at $532 \mathrm{~nm}$ with pulsed cavity ring down spectroscopy, J. Aerosol Sci., 35, 995-1011, doi:10.1016/j.jaerosci.2004.02.008, 2004.

Redmond, H. and Thompson, J. E.: Evaluation of a quantitative structure-property relationship (QSPR) for predicting midvisible refractive index of secondary organic aerosol (SOA), Phys. Chem. Chem. Phys., 13, 6872-6882, 2011.

Rohrer, F., Bohn, B., Brauers, T., Brüning, D., Johnen, F.-J., Wahner, A., and Kleffmann, J.: Characterisation of the photolytic HONO-source in the atmosphere simulation chamber SAPHIR,
Atmos. Chem. Phys., 5, 2189-2201, doi:10.5194/acp-5-21892005, 2005.

Salo, K., Hallquist, M., Jonsson, A. M., Saathoff, H., Naumann, K.H., Spindler, C., Tillmann, R., Fuchs, H., Bohn, B., Rubach, F., Mentel, Th. F., Müller, L., Reinnig, M., Hoffmann, T., and Donahue, N. M.: Volatility of secondary organic aerosol during $\mathrm{OH}$ radical induced ageing, Atmos. Chem. Phys., 11, 11055-11067, doi:10.5194/acp-11-11055-2011, 2011.

Schnaiter, M., Horvath, H., Möhler, O., Naumann, K. H., Saathoff, H., and Schöck, O. W.: UV-VIS-NIR spectral optical properties of soot and soot-containing aerosols, J. Aerosol Sci., 34, 14211444, 2003.

Shilling, J. E., Chen, Q., King, S. M., Rosenoern, T., Kroll, J. H., Worsnop, D. R., DeCarlo, P. F., Aiken, A. C., Sueper, D., Jimenez, J. L., and Martin, S. T.: Loading-dependent elemental composition of $\alpha$-pinene SOA particles, Atmos. Chem. Phys., 9, 771-782, doi:10.5194/acp-9-771-2009, 2009.

Spracklen, D. V., Jimenez, J. L., Carslaw, K. S., Worsnop, D. R., Evans, M. J., Mann, G. W., Zhang, Q., Canagaratna, M. R., Allan, J., Coe, H., McFiggans, G., Rap, A., and Forster, P.: Aerosol mass spectrometer constraint on the global secondary organic aerosol budget, Atmos. Chem. Phys., 11, 12109-12136, doi:10.5194/acp-11-12109-2011, 2011.

van Krevelen, D.: Graphical-statistical method for the study of structure and reaction processes of coal, Fuel, 24, 269-284, 1950.

Walser, M. L., Desyaterik, Y., Laskin, J., Laskin, A., and Nizkorodov, S. A.: High-resolution mass spectrometric analysis of secondary organic aerosol produced by ozonation of limonene, Phys. Chem. Chem. Phys., 10, 1009-1022, 2008.

Washenfelder, R. A., Flores, J. M., Brock, C. A., Brown, S. S., and Rudich, Y.: Broadband measurements of aerosol extinction in the ultraviolet spectral region, Atmos. Meas. Tech., 6, 861-877, doi:10.5194/amt-6-861-2013, 2013.

Wex, H., Petters, M. D., Carrico, C. M., Hallbauer, E., Massling, A., McMeeking, G. R., Poulain, L., Wu, Z., Kreidenweis, S. M., and Stratmann, F.: Towards closing the gap between hygroscopic growth and activation for secondary organic aerosol: Part 1 - Evidence from measurements, Atmos. Chem. Phys., 9, 3987-3997, doi:10.5194/acp-9-3987-2009, 2009.

Wiedensohler, A.: An approximation of the bipolar charge distribution for particles in the submicron size range, J. Aerosol Sci., 19, 387-389, 1988.

Wilson, E. M., Chen, J., Varma, R. M., Wenger, J. C., and Venables, D. S.: A Novel, Broadband Spectroscopic Method to Measure the Extinction Coefficient of Aerosols in the Near-Ultraviolet, in: Radiation Processes in the Atmosphere and Ocean, edited by: Cahalan, R. F. and Fischer, J., AIP Conference Proceedings, 155158, 2013.

Yu, Y., Ezell, M. J., Zelenyuk, A., Imre, D., Alexander, L., Ortega, J., D’Anna, B., Harmon, C. W., Johnson, S. N., and FinlaysonPitts, B. J.: Photooxidation of $\alpha$-pinene at high relative humidity in the presence of increasing concentrations of $\mathrm{NO}_{\mathrm{x}}$, Atmos. Environ., 42, 5044-5060, 2008.

Zhao, W., Dong, M., Chen, W., Gu, X., Hu, C., Gao, X., Huang, W., and Zhang, W.: Wavelength-resolved optical extinction measurements of aerosols using broad-band cavity-enhanced absorption spectroscopy over the spectral range of $445-480 \mathrm{~nm}$, Anal. Chem., 85, 2260-2268, 2013. 